\title{
OMAN AS POLE OF CULTURAL, MERCANTILE AND ECONOMIC BUSINESS BETWEEN EAST AND WEST
}

\author{
VALERIA PIACENTINI FIORANI (*)
}

SunTO. - Per capire l'importanza dell'Oman come polo culturale e mercantile e, allo stesso tempo, come perno politico e strategico nelle relazioni fra Oriente e Occidente, non si può prescindere dalla sua configurazione geografica e dal habitat umano che caratterizzano questa regione, di cui si accenna brevemente in questo discorso e in quello che segue. Si tratta di peculiarità che hanno avuto un profondo impatto sulla vita e la storia della regione per oltre cinque millenni, facendone un unicum nel contesto culturale dei mari che lo circondano e della stessa Penisola Arabica. Le evidenze archeologiche che stanno venendo alla luce confermano il ruolo dell'Oman come crocevia delle vie di terra e di mare. Per quanto riguarda l'Occidente europeo, fino a circa il secolo diciannovesimo viaggiatori ed esploratori descrivevano l'Oman come uno scatolone di sabbia, sassi e rocce - quanto più di inospitale potesse esserci - sprofondato nella nebbia delle leggende Bibliche della Regina di Saba e delle miniere di Re Salomone. Tuttavia, riesaminando alcuni documenti dagli archivi Italiani, e la ricca letteratura contemporanea in lingue Araba e Persiana (essenzialmente cronache, resoconti di viaggiatori e geografi, e codici commerciali), emerge un'immagine ben diversa, e le fonti, anziché contraddirsi, si integrano perfettamente. Da questi emerge l'importanza della posizione strategica dell'Oman all'imboccatura del Golfo, una posizione che, anziché dar vita a una florida pirateria, evolvette in una oculata politica di intese e alleanze matrimoniali con i paesi gravitanti sui mari circostanti, quali i potentati della fascia costiera Iranica e del Balochistan meridionale, l'India e l'Asia sud-orientale, e le coste orientali dell'Africa. E quando le relazioni fra popolazione delle coste omanite e comunità del hinterland si strutturò in equilibri sociopolitici e complementarità di servizi, allora l'Oman divenne il vero e proprio perno di nuove realtà politiche che diedero vita a veri e propri sistemi di terra e di mare. Nel discorso che segue, si esaminano alcune fasi ben precise della storia Omanita, quali il periodo del dominio Buyide (X secolo CE), il sistema politico costruito dai turchi Selgiuchidi (XIXIII secolo CE), e il regno di Hormuz fino all'arrivo dei Portoghesi (XVI secolo CE).

(*) Università Cattolica del Sacro Cuore, Milano, Italia.

E-mail: valeria.piacentini@unicatt.it 
Questi si distinguono per alcune realtà ben puntualizzate dalle fonti letterarie e le evidenze archeologiche, realtà che - si può dire -costituiscono l'identità dell'Oman fino ai giorni attuali. Ad esempio: l'interazione fra le genti del mare e le genti del hinterland, basata su una complementarità di rapporti e "servizi"; l'abilità di alcuni sovrani di evitare di essere coinvolti "a favore" o "contro" in caso di conflitti regionali, e di perseguire una politica basata sulla "inclusività" e non sulla "esclusività"; donde anche, la vitalità e il cosmopolitismo che regnò in determinate corti, e il dinamismo della popolazione che le circondava, fatta di comunità che convivevano attivamente fra loro in un vivace rapporto inter-religioso, inter-culturale e inter-etnico. Una realtà ben viva ancora oggi. Se poi si paragonano questi aspetti con determinate tradizioni del pensiero Islamico, è possibile rapportare queste realtà all'influenza del pensiero Ibadita sulle comunità Omanite, come verrà esplicitato nel discorso che segue.

$* * *$

ABSTRACT. - To understand the significance of Oman over the past centuries as mercantile and cultural pole and, at the same time, as political and strategic pivot between East and West, one cannot neglect the geographic distinctiveness, the geomorphological configuration and the human habitat of this region, outlined in this and in the following paper. These factors have always had a deep impact on its history for over five millennia, making of this territory a unique feature within the cultural context of the surrounding seas and the Arabian Peninsula. The archaeological evidence coming to light confirms the role played by the Omani lands as core and crossway of the major sea and land routes. With regard to the Occident, nearly up to the $19^{\text {th }}$ century AD, travellers and explorers portrayed Oman as an immense box full of sands and stones, lost in the mist of Biblical legends of the Queen of Sheba and the mines of King Salomon. Yet, in re-examining Italian archives and contemporary literary sources in Arabic and Persian (essentially chronicles, geographies and commercial codes), a different picture emerges. Its strategic location at the mouth of the Gulf has given Oman a privileged position that, rather than evolving into an active and profitable piracy, has developed in a balanced and well-calibrated network of understandings and matrimonial alliances with other countries surrounding or gravitating on these maritime spaces, such as the Persian seaboards and southern Baluchistan, Hind, Sind and south-eastern Asia, the eastern coasts of Africa and its city-states. And when the relationship between the hinterland and its peoples, on the one hand, and the communities of the coastal areas and their socio-political paradigms, on the other, developed a high compatibility, then Oman stood out. Stood out as pivot of new territorial and maritime systems. In this paper, I will linger on some specific epochs of the Omani life and history, in particular on the Buyid dominion, the Seljuk political organisation, the kingdom of Hormuz up to the arrival of the Portuguese (16h Century CE). Specifically, the aim is to focus some features that represent the identity of Oman, such as: the special interaction between the peoples of the hinterland and the peoples of the sea; and, with the words of $\mathrm{Al}$ Salimi in his discourse, the ability of the rulers to avoid being drawn into a "pro" or "anti" camp when some conflict arose, and their belief in "inclusivity" and not exclusivity and rejection; thence, the liveliness of some cosmopolitan courts and the multicultural and inter-ethnic and religious human milieu surrounding them. At the end, by comparing these features with some intellectual traditions developed in the Islamic thought, it can be possible to trace them to the influence of Ibadi thought on the Omani communities, as dealt with in the following discourse. 


\section{Desert, MOUNTAin, MARSH AND SEA}

To understand the significance of Oman over the past centuries as mercantile and cultural pole and, at the same time, as political and strategic reality between East and West, Dr 'Abdulrahman Al-Salimi's geographic picture of "historic" Oman (or the Greater Oman, as he calls this region in his paper) is a perfect lens to define it:

“....an inhabited island occupying the south-eastern corner of the Arabian Peninsula. It is surrounded by sea on three sides, while its land side is cut off from the rest of Arabia by the rolling sand dunes of the Empty Quarter, or Rub al Khali. In the centre of the country is a long mountain range extending from the Musandam Peninsula to Ras al-Hadd, while to the south a barren expanse of stony desert and salt flats stretches to Dhofar and the "Greater Yemen", and along the Gulf's coast towards the State of Qatar and "Greater Bahrain".

This geographic distinctiveness, the geomorphological configuration of this region and its human habitat have had a deep impact on the history of Oman for more than five millennia, making of its territory a unique feature within the cultural context of the surrounding seas and the Arabian Peninsula. The archaeological evidence coming to light confirms and enhances the role played by the Omani lands as crossway - if not "the crossroad" - of the major mercantile land and sea routes since ancient times. At the same time, its castles and dominant forts (Salalah, Shihr, Sur, Qalhat, Muscat, Rustaq, Sohar, Diba', Julfar/Ras al-Khaymah...just to mention some of them along the seaboard), and yet, in the hinterland, the commanding fortresses of Izki, Nizwa, Bahla, Buraimi, al-Sirat... underline its strategic significance at the entrance of the Gulf (Figs. 16-19). The Arabian desert is a wilderness of sand dunes surrounded by featureless gravel plains even more lifeless; it stretches for about nine hundred miles from the foothills of the Yemen up the last mountainous slopes of the Omani range, and for five hundred miles from the Indian Ocean to the Gulf. "It is a desert within a desert - stated Wilfred Thesiger - which even the Arabs call Rub' al-Khali, the Empty Quarter...or also the Arabian Nightmare" ${ }^{1}$. It is an immense space indeed, which has always repre-

1 W. Thesiger, Desert, Marsh and Mountain, Flamingo - Harper Collins Publishers, repr. London 1995, p. 33. Wilfred Thesiger is one of the greatest British 
sented an impregnable natural barrier, a positive challenge to those who dared to cross it.

For the Occident, nearly up to the very beginning of the twentieth century, travellers and explorers portray Oman as an immense box full of sands and stones, lost in the mist of the Biblical stories of the Queen of Sheba and the mines of King Salomon, its hilly rocky hinterland dominion of wild, ruthless peoples. Inner and Southern Oman in particular were generally figured as a forbidden and forbidding land of pirates and a no-man land of warring tribes moving over great distances seeking pasture for their camels. Except for some coastal areas and a few towns, European maps were still blank. However, a few decades later, these terrific images began to dissolve. The "impenetrable" lands of the Omani sheikhs and their tribes opened up. By the second half of the century, travellers, scholars, historians, archaeologists were welcomed. Today, written sources and archaeological data allow us to depict a well different and differing fresco.

\section{HiNTERLAND AND COASTAL AREAS: WHICH EQUILIBRIUMS AND INTERACTION?}

Since pre-Islamic eras, the Omani coastal regions were the reign of mangroves, dhows (the traditional boats of the region), fishermen and pearl-divers. The few banadir and ports - well protected by the seasonal winds that ravage this coastal region - were inhabited by a mobile, cosmopolitan humanity of every language, religion and colour. There, it was possible to bargain and buy the most precious merchandise. Water was fresh and abundant in the wells; and passing on convoys were furnished also with fruits, vegetables and meat. The surrounding lands and villages, irrigated thanks to human skilled interventions (a chanals-system, or falajlaflaj), blossomed out; gardens and orchards produced all kinds of

travellers amongst the Arabs, the first European to cross the parched Empty Quarter in the forties of the nineteenth century, following in the tradition of Burton, Thomas, Doughty, Lawrence and Philby. Educated at Eton, in 1935 he joined the Sudan Political Service, and, at the outbreak of the war, was seconded to the Sudan Defence Force. Since the war, he travelled in still so called "blank regions". Another vivid account of Arabia is his Arabian Sands, Penguin Books, repr. 1984, where he describes his journeys across the "Empty Quarter" and "Inner Oman". 
greenery. Since pre-Islamic times, the palm groves and cultivated fields surrounding Sur, Muscat, Rustaq, Sohar, Julfar... were renowned all over the world (Figs. 20-22). But Oman is not only a prosperous seaboard. Oman is also its hinterland with its steep, indented rocky mountains and deserts, a traditional home environment which was - and still is - inhabited by nomadic/seminomadic groups and settled peoples, practicing a traditional life structured in the traditional tribal system, and practicing a prosperous agriculture on the basis of the traditional, sophisticated aflaj system (like Bdiya, Irbid, Nizwa, Bahla etc.)2.

As just stated above, Oman can be figured as an "island". Yet, what makes this island a notable reality within the general Arab panorama, is the complementarity which can unite the coastal human environment with the traditional human environment of the hinterland. Then, the hinterland is no longer a hostile and impenetrable territory. It is a geographic and human environment per se, a vast space which however, in given epochs, has had lively intercourses with the seaboard; it interacted with its peoples either trading with them or furnishing excellent land military corps and/or escorts for pilgrims and passing on caravans, or both.

History has regularly noted this reality in its chronicles and geographies. The archaeological evidence has enhanced this peculiarity, providing a "modern" comprehension of this puzzling region with all its ramifications, models of life and patterns of settlement. Literary sources com-

2 R.B. Serjeant, Farmers and Fishermen in Arabia, Collected Studies Series Variorum Reprint, Ashgate Publishing Limited, Aldershot/UK - Brookfield/USA 1995; Idem, Society and Trade in South Arabia, Collected Studies Series Variorum Reprint, Ashgate Publishing Limited, Aldershot/UK - Brookfield/USA 1996. J.C. Wilkinson, "Traditional Concepts of Territory in South East Arabia", in Geographical Journal, 149 (1983), pp. 301-315; Idem, "The Origins of the aflaj of Oman", in Journal of Oman Studies, 6 (1983), pp. 177-194; Idem, "Muslim Land and Water Law", in Journal of Islamic Studies, 1(1990), pp. 54-72; Idem, Water and Tribal Settlement in South-East Arabia. A Study of the Afläj of Oman. Vol. V of the Series Al Salimi, A. and Gaube, H. (eds.). Studies on Ibadism and Oman. Georg Holms Verlag, Hildersheim Zürich - New York 2015. Though from a different perspective, a sharp analysis of the transition from the traditional models to modernity, and local cultural resistance to changes and absorption of new elements within modern/post-modern patterns of life, can be found in the studies by Mashary A. Al-Naim, The Home Environment in Saudi Arabia and Gulf States. The Dilemma of Cultural Resistance. Identity in Transition, 2 volumes, series CRiSSMA Working Paper ns. 10-11, EDUCatt - Università Cattolica del Sacro Cuore, Milano 2006; Frauke Heard-Bey, From Trucial States to United Arab Emirates. A Society in Transition, Motivate Publishing, Dubai - Abu Dhabi - London 2013 (revised and updated version from the $1^{\text {st }}$ edition, Longman1982). 
bined with archaeological evidence provide new precious clues and allow us to understand the very forces that are also the current developments in this country.

Thus, we have a different overall picture. Within a worldwide network of cultural and mercantile communications, Oman - projected on three seas (the Indian Ocean, the Arabian Sea and the Gulf) - has always been a land of sailors, enterprising merchants and experienced fishermen. Its strategic location at the mouth of the Gulf has given Oman a privileged position that, rather than evolving into a lucrative piracy, has developed in a balanced and well-calibrated network of understandings and matrimonial alliances with other countries surrounding or gravitating on the same maritime spaces, like the Persian seaboards and southern Baluchistan, Hind, Sind and south-eastern Asia, the eastern coasts of Africa and its city-states, in particular. And when the relationship between the hinterland and its peoples, on the one hand, and the communities of the coastal areas and their socio-political paradigms, on the other, developed a high compatibility, then Oman stood out. Stood out as pivot of new land and maritime systems.

Then, its socio-political and cultural order became the backbone of an economic network of business and political power, which was to give this region a character and a culture of its own. Then, we are confronted with a reality (at the same time a positive legacy), which would mould the life of Oman for centuries (if not millennia), and, with it, its same cultural identity through new experiences, traditions and images. It consists in a continuous modification that survived the course of the time, endured domestic wars and strife, attacks and military occupation. It consists in the redefinition of cultural traditional values that resist all changes through the regeneration of the society during transitional times and the assimilation of new concepts, which will be re-forged in a fresh social identity which, despite all, did not sign any break with tradition and the past ....an experience that written sources combined with archaeological evidence depict with clarity, an experience that is part of current times and we have been witnessing during these last decades, when the inhabitants of the hinterland and its traditional areas began to leave it for new "modern" habitats and new opportunities".

3 In Oman, undoubtedly this transition has been largely shaped by Ibadism and its traditional principles and values, see below and following paper. For an in-depth approach to historical events and the transition to new "modern" models of life, see above note 2 . 
3. HiSTORICAL FLASHES: THE BUYID MILITARY MARITIME SYSTEM: 'UMĀN, AN OVERSEAS PROVINCE. THE SELJUK ART OF NEGOTIATION AND GOVERNMENT: THE WILAYAT-I 'UMĀN. HORMUZ AND ITS LEGACY: 'UMĀN "ABODE OF SECURITY” AND ALLY

In his discourse, Al-Salimi gives a lucid analysis of this latter issue and the role played by Ibadism. Conversely, the following notes aim at pinpointing some "Islamic" periods of the history of Oman, in which the Omani society and its political-institutional structures achieved and executed those well calibrated equilibriums that did actually prove to be particularly significant when interacting with other political powers at sea and on land, thus making of Oman the hinge of positive land and maritime systems.

Let us focus, for example, on the tenth century CE, at the time of the Buyid dominion and their overseas initiatives. Many scholars have written at length about this issue, amongst them Al-Salimi, J.C. Wilkinson and the present author. The rereading of some passages by contemporary literary sources suggests that the main Buyid overseas objective was neither a stable, long-term occupation of Oman nor individual initiatives aimed at plundering, but the establishment of indirect, yet extremely firm, military control over the adjoining Arabian coast and the restoration of order in a region that had collapsed into renewed civil and religious strife with the disruption of the Ibadi Imamate and the death of Yusuf ibn Wajih (c. 952), the last strong Wajihid ruler5.

\subsection{The Buyid Military Maritime System}

Taking into account the general political picture, towards the start of the second half of the tenth century the Buyid dominion was chal-

4 See Figs. 4-13.

5 Ibn al-Athir, Al-kāmil fī al-tārīkh, ed. C.J. Tornberg, 13 volumes, Leiden 1851-1876, vol. viii: p. 565, 568; Ibn Miskawaykh, Tajärib al-umam - The Eclipse of the 'Abbasid Caliphate, ed. and tr. H.F. Amedroz and D.S. Margoliouth, 6 volumes, Oxford University Press, Oxford 1920-1921, vol.ii: pp. 196-197,217-218. See also Abdulrahman Al-Salimi, "Makramid Rule in Oman", in Proceedings of the Seminar for Arabian Studies, 35 (2005), pp. 223-254; Idem, "Coins of the Omani Imams during the Buyid Period. Studying the Bahla Hoard", in J. Korn, E. Orthmann and F. Schwarz 
lenged by serious territorial problems in Mesopotamia, uprisings in its eastern regions, Fatimid claims, the weakness of the Caliphate, and the political arrogance and military superiority of the Qarmatians (or according to the Arabic pl. form - Qarāmita). For Arabia and Oman, these latter were a major threat. By the end of the ninth century, taking advantage of local social discontent and the chaos left by Zenj rebellions, they had built up a vigorous and enduring state. Without entering into the philosophical and theological disputes and clashes which were at the core of more than one military campaign or alliance, the Qarmatians, taking advantage of both the confused situation in Mesopotamia and the power vacuum in Oman and the southern Arabian regions, had spilled into Arabia and the Gulf, entering the western waters of the Indian Ocean. The main centre of Qarmati activity was in Bahrain, that is a region then defined as the coastal region of eastern Arabia up to the lands of the Bedouins of the Syrian and Arabian deserts. Thence, they thrust towards Oman and Sohar. All along the eastern Arabian costal region, they built a chain of massive strongholds up to Buraimi, whence they could exert tight control on the magnificent city-harbour of Sohar and the Omani seaboard and hinterland $d^{6}$. This was the hinge on which the following events turned.

(eds), Die Grenzen der Welt. Arabica et Iranica ad honorem Heinz Gaube, Reichert Verlag - Wiesbaden 2008, pp. 181-188; Idem, “The Wajīhids of Oman”, in Proceedings of the Seminar for Arabian Studies 39 (2009), pp. 372-381. J. C. Wilkinson, Ibâdism. Origins and Early Development in Oman, Oxford University Press - Oxford 2010. V. Piacentini Fiorani, "The Growth of the Relationships between Oman, the Gulf and the Western Waters of the Indian Ocean. Oman: the Corner-Stone f a Maritime System", in M. Hofmann-Ruf (ed.), 'Oman and Overseas'. Proceedings of the International Conference 'The Ibadism of Oman - Its Overseas Development and its Perception Overseas' beld at Tübingen University 16 $6^{\text {th }}-19^{\text {th }}$ May 2011, Georg Olms Verlagsch buchhandlung, Tübingen 2012, pp.143-182; Idem, Beyond Ibn Hawqal's Babr al-Fārs.10 ${ }^{\text {th }}$ $13^{\text {th }}$ Centuries AD: Sindh and the Kìj-u-Makrān region, hinge of an international network of religious, political, institutional and economic affairs, vol. 2 of the series 'Studies in the Archaeology and History of Baluchistan', Bar International Series n. 2651, Archaeopress - Oxford 2014, specie pp.83-98 (and herewith given sources and references). With regard to the Buyids, their rise to power, their military organization and shi $i$ Islam, their understandings with the Caliphate, their vast empire and dominion, surrounding dynasties, tribes, cities and social organization, visual arts and sciences: R.N. Frye (ed.), The Period from the Arab Invasion to the Saliuqs, vol. 4 of 'The Cambridge History of Iran', Cambridge University Press - Cambridge 1975.

6 The geographical and geopolitical map of the time, as clearly shaped by 
The Qarmatians were infantrymen, not seamen and did not, in general, have any indigenous traditions of seafaring. Their might and power was on the land. Sand dunes, deserts and rocky mountains were a familiar environment. But, when confronted with the sea, they needed an ally, which fact offers a good explanation of their aggressive policy towards Sohar in particular: here, they repeatedly tried to acquire the naval resources of Oman and the services of its maritime population. During the first half of the tenth century, they had already tried to take control of the Gulf's maritime trade and pilgrimage routes through Sohar and the coastal provinces. Ibn Wajih, the Ibadi ruler of Oman, had managed to pursue a balanced policy between the Qarmatian ambitions, the Abbasid Caliphate and the Buyid "military protection" of the latter, both through action and peaceful diplomatic initiative.

However, regardless of Ibn Wajih's balanced policy, around 952 the Qarmatians dealt a serious blow to Buyid economic interests when they set out a military campaign, with — it would seem — the maritime complicity of Yusuf ibn Wajih (the last strong Wajihid Ibadi ruler of Oman), conquering the northern regions of the Persian Gulf, including the harbours of al-Ubulla and Basra, whence ships sailed to and from India. This was a direct menace to Fars, too, and its mercantile supremacy at sea. The attack resulted in a sharp confrontation for maritime supremacy and control over the Gulf and the Indian Ocean. Buyid military strength was based on land troops, too. But, the two main harbours along the Iranian seaboard, Siraf (Fars) and Hormuz (Kerman), stood loyal to the Buyids ${ }^{7}$. At this juncture, Qarmatian arrogance and new dynastic confusion in Oman forced the Buyid Mu izz alDawla to take firm action in 962-963 in order to restore order once and

chroniclers and geographers, in no way contradicts the archaeological horizon. Bahrain was a vast region, the "historic Bahrain" as described by Al-Salimi, with the rich oases of Hufuf and Qatif, the core of Qarmatian power. They also had strongholds all along the eastern seaboard of Arabia. Derek Kennet (Durham Univ.) and Timothy Power (UCLA Univ.), amongst other archaeologists, have unearthed notable and significant Buyid evidence and Qarmatian material, that confirms the literary evidence. Timothy Power, in particular, is digging a magnificent site at Buraimi dating to the $10^{\text {th }}-12^{\text {th }}$ centuries CE; see in this regard, T. Power's papers read at the International Seminar on the Gulf held at Abu Dhabi, NYUAD ( $8^{\text {th }}-10^{\text {th }}$ July, 2016), and at the Seminar for Arabian Studies (July $29^{\text {th }}-31^{\text {st }}, 2016$ ).

For references, see above note (5). 
for all in the sensitive regions of Oman (hinterland and seaboard), and to ensure safe passage through the Strait of Hormuz for convoys to and from the Indian Ocean. I will not enter into further detail about the military events. The Buyid campaign was - not without heavy losses and harsh fighting - successful ${ }^{8}$.

One point however deserves special attention. Here, literary sources provide an interesting information: they duly record how - during the troubled period of the disruption of the Ibadi Imamate in Oman, following unrests and Qarmatian attacks - peoples from Oman sought refuge on the Iranian seaboard, Kerman and Makran up to the mouth of the Indus delta, where Arab communities from Oman had already established agricultural and trading activities a couple of centuries earlier if not before. There, they were welcomed and hosted, and there they settled taking with them their riches and faith, Ibadism?

From the general picture, it follows that the support of Siraf and its merchant families on the one hand, and the ruler of Hormuz, who chartered Buyid troops to and from Oman with his fleet, on the other, and the allegiance of the Arab communities were a key-factor to the success of the whole military operation. This is a precious flash for more than one reason. First of all, it sheds an appealing light on the spe-

8 Ibn al-Athir, Al-kāmil...cit., viii: 417-420, 426, 448-449, 451-452, 474, 565, 568 ff.; Ibn Miskawaykh, Tajārib al-uman ...cit., ii: 196-197, 217-218; vi: 277, 280, 298; Bayhāqī, Tārīkh-i Mas'ū $\bar{u}, 3$ volumes, Eqbāl - Tehran 1319-1333/1940-1941, i: 42. See also C.E. Bosworth, "The Banū Ilyās of Kirmān (320-357/932-968)", in: C.E. Bosworth (ed.), Iran and Islam. In Memory of the Late Vladimir Minorsky, Edinburgh University Press - Edinburgh 1971, pp. 107-124; J.C. Wilkinson, A. Al-Salimi's and Fiorani Piacentini's studies cited above note (5).

9 See above note (5) and Al-Salimi, "Coins of the Omani Imams...", specie p. 377. It is possible to assert that these families were either seeking shelter from the unrest that was devastating Oman, or settled there in order to profit from the situation following the collapse of the first Imamate, and carry out their own business by controlling or diverting shipping and trade. For example, we have the names of the Julanda ibn Karkar of the Banu 'Umarah clan, which controlled the Ramm al-Kariyan in Fars; the Banu Salima, who left Oman to settle in Kerman; the Qawasim; and the Tibis, whose interests by that time would be closely allied with those of Siraf. However, migratory waves had already taken place before Islam, and later on at the time of the Arab conquest of Sindh from Yemen and the south-eastern regions of Arabia. These latter had settled in Sindh and Baluchistan, holding relevant positions during the Umayyad and early Abbasid Caliphate: V. Piacentini Fiorani, Beyond Ibn Hawqal's Bahr al-Fārs... , cit., pp. 35-80. 
cial character of the Gulf and adjoining seas' society (merchants, farmers, sailors and fishermen) and the mobility of their communities, their cosmopolitan afflatus, and the understandings and matrimonial links that have always given to these liquid spaces an identity of their own. Moreover, it explains how and why - from the political and military point of view and within the recomposed Buyid order - the organization of entrepôt trade was in favour of the Iranian landmass and the eastern and southern regions of the Arabian Peninsula. Actually these scraps of information cast a new light on the policy of 'Adud al-Dawlah (949-983), too, the farsighted Buyid Lord, brother of Mu'izz al-Dawlah, who had supreme command within the Buyid system. He did not fail to realize the significance of the special geographical and environmental reality of Oman when dealing with maritime intercourses, and, at the same time, the significance of the delicate relationship between the Omani seaboard (and its communities) and the hinterland (with its population of farmers and nomadic/seminomadic groups). He directed his political efforts to consolidate the Omani acquisition and recompose the traditional equilibriums in a complementarity. Sporadic raids and strife continued throughout the following decades, as punctually recorded by chronicles, but - through the "militarisation" of the eastern regions and part of the southern ones up to Shihr - he managed to achieve a sort of permanent compatibility that would give to Oman its enticing position of "pole" of cultural, mercantile and political relations between East and West.

This polity was based to a great extent on a network of regional family links and interests, as clearly flashed out by literature. However, turning to the Arabian stage in particular, geographies of the second half of the century add new significant scraps of information ${ }^{10}$. The

10 Istakhri, Kitāb al-masālik wa al-mamālik, ed. M.J. deGoeje, Bibliotheca Geographorum Arabicorum, Brill - Leiden 1870; Ibn Hawqal, Kitāb sūrat al-ard, ed. M.J. deGoeje, Bibliotheca Geographorum Arabicorum, Brill - Leiden 1967 (photo mechanical reprint from the second revised edition 1906); Al-Muqaddasī, Absan altaqāsìm fì al-ma'rīfat al-aqālìm, ed.M.J. deGoeje, Bibliotheca Geographorum Arabicorum, Brill - Leiden 1967 (photo mechanical reprint from the second revised edition 1906); Anonymous Author, Hudüd al-'Alam, ed. V. Minorsky and V.V. Barthold, E.J.W. Gibb Memorial Series vol. XI - Oxford University Press/Luzac - London 1937. Archaeological evidence perfectly matches with literature (see M. Kervran's studies on Bahrain and Sohar - see below note 11; A. Rougeulle's precious book on Sharma 
organization of the whole Buyid structure appears to have been tilted in favour of some of the southern regions of Arabia on the one hand, and the mighty fortifications built (or re-built) all along the eastern coasts of the Peninsula and at the main mountain passages with the deep interior. In other words a "militarised Oman", planned however to defend "with fully-equipped and permanently stationed guards" the coastal communities from raids and pillaging from the sea, and provide security and safe transit to and through the hinterland for caravans and travellers (and possibly levying duties on them). But we have also knowledge that, in more than one occasion, when a serious danger approached and threatened the centre (such as renewed Qarmatian and Ghaznavid incursions), the people of the interior (farmers and nomadic groups) used to rise in arms against these foreigners, providing safe shelter to the people of the coastal towns and settlements, and, when requested, they also furnished them with land troops to contrast rebels or invaders. A complementarity, a unity, a formidable interaction at war and in peace. The mountains and their forts represented a special niche, defence and sanctuary at the same time when a land or sea attack endangered the peoples of the seaboards, becoming the heart of the resistance and, then, of the response that usually turned up successfully thanks to the solidarity of the population and the various tribal segments (the photographic insert well portrays this state of affairs: well fortified castles in commanding position watching strategic passages and blossoming oases, their mighty bastions and walled enclosures that, when needed, became sanctuary and shelter for the population settled in the surrounding villages and/or passing on convoys) (Figs. 16-19).

The only exception within this "militarized" panorama was that of Sohar. By now, Sohar stems out as one of the main handling centres in Arabia for trade along the monsoon routes, both inside and outside the orbit of the Gulf. Trade in the Indian Ocean was also flourishing: the southern coast of the Arabian Peninsula was densely populated and rich in minor and major centres, where trade and other activities pros-

(A. Rougeulle ed., Un entrepôt de commerce medieval sur la côte du Hadramwt (Yémen, ca 980-1180), British Foundation for the Study of Arabia - Monographs n. 17, series editors: D. Kennet \& St J. Simpson, Archaeopress - Olywell Press, Oxford 2015); C. Hardy-Guilbert's excavations on the southern coasts of Arabia; recent excavations at Rustaq, Kalba, Diba, Jumairah, Julfar, Kush, Buraimi and many other sites come to light in these last years). No less precious is the evidence provided by numismatics. 
pered, such as farming, craftsmanship, agriculture, pearling, fishing. Facing the Arabian Peninsula, other important outlets and terminals of the monsoon routes were Suru and Hormuz, Jask and Jaghin along the coasts of the Garmsirat, Tiz further east, then Armabil along the Makrani coastal area, before reaching Sindh and the great harbour town and port emporium of Daybul/Debol on the delta of the Mihran river (present Indus river). Hereafter, Omani history and events cannot be dissociated from what was taking place in Kerman and Makran, Sindh and Hind.

With the Buyids, Oman, Makran and Sindh entered a systemic military, political-institutional vision, represented a compact territorial region vital to the mercantile welfare of Fars in primis, since they hosted the major outlets and harbours of the time and controlled the key access to and from the Gulf and the western waters of the Indian Ocean. But not only this; soon they entered the overall political and economic vision of the Buyid empire, institutionalized and structured in a positive system. Of this land and maritime system, as just said above, Oman and Sohar stood as the pivot.

Here, a few decades later, flourished the Mukramid (or Makramid) court, a cosmopolitan, tolerant court where arts, philosophy, science and poetry were highly valued ${ }^{11}$.Then, Sohar was the town par excellence of Oman (shahr and madina), a "Great Oman", that included Julfar (present Emirate of Ras al-Khaymah) and reached the territory of today Abu Dhabi, bordering with the "Great Bahrain" just described above. Sohar - with its large harbour surrounded by palmgroves, prosperous villages where sophisticated crafts were practised, well cultivated fields - was at that time well-liked by the merchants that conveyed there to bargain and sell their goods, fascinated by its superb Mosque standing up by the sea and adorned with the most brilliant colours, as it is described by Muqaddasi who travelled there at the end of the tenth century. There, an active and pluralistic society prospered, multi-ethnic and multi-religious, well mirrored by Sohar's commercial codes. There, ships from every corner of the world used to call, from

11 See in particular A. Al-Salimi, "Makramid Rule in Oman", in Proceedings of the Seminar for Arabian Studies, 35 (2005), pp. 247-253, and V. Piacentini Fiorani, "Suhār and the Daylami Interlude (356-443/967-1051)", in Proceedings of the Seminar for Arabian Studies 34 (2005), pp. 195-206. 
the Levant and the Orient, from China and Malaya, from India and the eastern coasts of Africa. Sohar was also a renowned centre of Islamic learning and culture; there, at its schools, the rich families of the merchants of the Gulf used to send their sons to learn about Islamic Law (figh) and trade. In these same schools, Omani officials were educated and trained in the art of business, destined to become the backbone of the local and overseas administrative state-apparatuses, thus creating an even more precious network of financial-economic and...matrimonial alliances, too ${ }^{12}$.

\subsection{The Seljuk art of negotiation and government. reorganisation and consolidation of the Buyid maritime system. The rise of Oman to milestone of the structure}

The Buyid empire crumbled down towards the end of the tenth beginning of the eleventh century under the disrupting blows of surrounding principalities. The final blow took place when new peoples spilled from Inner Asia through the Iranian landmass: the Seljuk Turks. Yet, the maritime system set up by the Buyids did not disintegrate; its conception was assimilated and regenerated by the sagacious strategy and organising force of a Seljuk sultan, Qavurd Khan ibn Chaghri Beg (1041-1073). Qavurd Khan, eldest son of Chaghri Beg, well experienced in the arts of negotiations and government, did not hesitate to turn the Seljuk military occupation of Kerman, Makran and Oman into a fruitful "allegiance". This move gave life to a territorial and maritime "trilogy", whose axes were the Iranian Kerman, the Baluchi Makran, and Oman (...at least its seaboard). The apexes of this territorial block encompassing the southern waters of the Gulf, the Arabian Sea and the western waters of the Indian Ocean were the harbour-town of Hormuz in Kerman, the fortified town of Kij in Makran along a formidable westeast land caravan route, and the harbour-town of Sohar in Oman.

12 With regard to Sohar, among the many scholars that carried out researchwork on this site and wrote remarkable studies, see M. Kervran, "Fortresses, entrepôts: une histoire à suivre depuis les rois sassanides jusqu'aux princes d'Ormuz", in C. Cahen, R. Curiel and R. Gyselene (eds.), Itinéraires d'Orient: hommages à Claude Caben, Res Orientales - Peeter Press, Leuven 1994, pp. 321-524; Idem, "Archaeological Research at Suhār, 1980-1986", in The Journal of Oman Studies, 13 (2004), pp. 263-381 - and herewith cited sources and bibliographical references. 
By the sixties of the eleventh century, we are confronted with a compact, homogeneous structure, fulcrum of new political and maritime power balances, which would mark the rising influence of Oman with its coastal Ibadi sheikhdoms and the traditional tribal structures of the interior. Kerman and the Kij-u-Makran were organised as autonomous administrative sub-divisions (nāhiya) ruled by a native amīr, within the Qavurdid sultanate of Kerman. Oman became a wilāyat - or administrative district - headed by a Seljuk wali (or governor) from the Seljuk family and lineage ${ }^{13}$.

Let us quickly glance how events evolved in Oman. Literary sources inform us that Qavurd Khan - only after having conquered and subdued the two provinces of Kerman and Makran, and after his harsh defeat in Sindh by the stern resistance of its harbour-townDaybul turned his attention to the other side of the sea, where Oman stood. Oman, whose links with Makran and Kerman had always been close, was renowned for its active population, copper mines, well-sheltered ports, pearls fisheries, horses, and other precious goods stored and traded there. At the same time, however, Oman was once again witnessing a phase of turbulence, banditry was threatening land routes and

13 V. Piacentini Fiorani, "The eleventh-twelfth centuries: an 'Umān-KījHarmuz/Kirmān axis?”, in Proceedings of the Seminar for Arabian Studies, cit., pp. 261276. Idem, Beyond Ibn Hawqal's Babr al-Fārs...cit., pp. 99-119,139-144ff. With regard to the Seljuk peoples, and the period and events here taken in consideration, a masterly overview still is that by C.E. Bosworth, "The Political and Dynastic History of the Iranian World (A.D. 1000-1217)", in J.A. Boyle (ed.), The Cambridge History of Iran, volume v, Cambridge University Press - Cambridge 1968, pp. 1-202. Cfr. also V. Piacentini Fiorani, Beyond Ibn Hawqal's Bahr al-Fārs...cit., pp. 99-144 and herewith given references. Amongst literary sources, with specific reference to Oman and the Sea, chronicles are particularly telling, both regional and general. Though we are confronted with a typical court genre, this material - when carefully sifted - can provide valuable information. The following discourse has essentially been based on Ibn alAthīr, Al-kāmil...cit., vol. ix, pp. 346, 334-354, 381-382, 398-400; vol. x, p. 111ff.; Juzjānī, Tabaqat-i Nāsirī, ed. 'Abd al-Hayy [translation H.J. Raverty London 18811899], 2 volumes, Kabul 1963-1964, pp. 103-104, 107; Mīrkhwānd, Rawdat al-safā' fī sìrat al-awliyā wa al-muluk wa al-khulafā', 10 volumes, Intishārāt-i Baniyād - Tehrān 1960, vol. iv, p. 105ff.; Muhammad ibn Ibrāhīm, Tārēkh-i Saljukiyān-i Kirmān, in "Recueil des Textes relatifs à l'Histoire des Seljoucides" vol. i, H. Th. Houtsma ed., Brill - Leiden 1886, pp. 2,4, 5, 7-8, 8-10ff.; Ahmad Vazīrī, Tārīkh-i Kirmān, ed. Muhammad Ibrāhīm Bastānī Pārīzī, 2 volumes, Intishārāt-i 'Ilmī - Tehrān 1961, vol. i, pp. 343-353ff. 
piracy infested the seas ${ }^{14}$. But not only this. Ibn al-Athir adds that, when the son of Chaghri Beg decided to recompose the "triangle" envisaged by the Buyid political and military line, Oman was under the control of one of the last Buyid princes, Abu Kalijar Marzuban, who, in 1034, had organised an expedition to Oman where he had had an easy task to eject the garrisons of other peoples of Turkish stock, the Ghaznavids, that, lured by Omani riches and the opportunity to control the straits and levy profitable tolls from the local population and passing convoys to and from the Indian Ocean, had wrested this province from the Mukramids ${ }^{15}$. However, after Abu Kalijar's death (1046 c.), the situation had become more and more confused: renewed Ghaznavid and Qarmatian attacks were laying waste the seaboard; Sohar was the target of two military expeditions and an occupation in 1051; at the same time, in the hinterland where Ibadism was still a social and religious presence deeply rooted among the tribal groups, a new Ibadi Imamate had reorganised under al-Khalil b. Shadhan, that brought to the 1051

14 According to some scholars, it has been assumed that the Seljuk overseas initiative was aimed at countering the Red Sea competition with the "political" and "cultural" unity of the southern waters of the Gulf and the western waters of the Indian Ocean. However, rereading Muhammad ibn Ibrāhīm's chronicle and the Târīkh-i Kirmān, it is possible to recognize that these latter match the crisp information given by Ibn al-Athīr, and allow us to see, beyond the preliminaries of the Omani enterprise, other major targets. Firstly, the firm containment of Ghaznavid and Qarmatian ambitions in the region and pirates' attacks. Mahmūd the Ghaznavid's expedition against the Jats in Sindh (1027) shows that this latter could mount a naval force (Gardìzī, Zain alakbbār, Berlin 1928, pp. 88-90). Secondly, beyond this assumption, it is also possible to read the continuation of Chaghri Beg's policy and his long exhausting campaigns in Central Asia aimed at contrasting, negotiating and achieving the consolidation of the frontiers with the Turks of the steppes and neighbouring empires all along the northeastern territories of the Seljuk dominion, and securing peaceful relationships and new rich markets through pacts and alliances. Thirdly, one can also read a well-planned strategy and a positive collaboration between Chaghri Beg and his son Qavurd Khan, aimed at reinforcing the frontiers also in the south-eastern regions of the Iranian landmass (Kerman, Makran and the Garmsirat) and revitalizing old land caravan routes and settled life by opening new land routes to the sea, a suitable alternative to the old ones that laid open to piracy and bandits' attacks. Oman and a firm control on its seaboard meant the closing of the circle: the milestone of the whole system. Then, read through this lens, the consolidation of the Hormuz-Makran system stands out as a Seljuk strategic priority. The Omani undertakings represent the logical development of the Seljuk conception of "territorial dominion" and "maritime system".

15 Ibn al-Athīr, Al-kāmil...cit., vol. x, pp. 310, 313. 
attack and occupation of Sohar and religious strife; war was waged to Bahrein, and new turmoil broke up in Hadhramawt and Yemen. Omani sources are silent, but Ibn al-Athir - always punctual and reliable in his information - states that these latter events were the casus belli that, in the fifties of the eleventh century, urged Qavurd Khan to take action in Oman, and that this sultan was the very architect of the Seljuk policy in this region, firmly supported by his father Chaghri Beg and the Great Sultan himself. Qavurd's military operations were successful. The Qarmatians, badly crushed,were forced to abandon their ambitions and Qavurd asserted his primacy "on the seaboard". Despite some expeditions in the hinterland (reported by Ibn al-Athir and the Tārikhb-i Kirmān) and towards Bahrein and Yemen aimed at preventing that tribal and religious feuds could again upset the coastal area, he did not interfere in the affairs taking place in the inland areas, setting up (or refurbishing) a chain of fortresses, stern sentinels of the mountain passages. His prime concern was to guarantee stability in the Gulf and adjoining seas ${ }^{16}$.

Vaziri and Muhammad ibn Ibrahim inform us that Qavurd Khan loved his domain and used to spend several months a year in Oman, enjoying hunting and roaming with his retinue in the vastness of the hinterland or in the green luxuriant oases along the coastal area. Following Buyid strategy and tactics, he reinforced the militarization of the coastal area, building watch towers and erecting or refurbishing pre-existing fortresses. He also built cisterns, bridges, and caravanserais, revitalizing the local cultural atmosphere, encouraged pilgrimage, and persuaded foreign merchants to come and settle, being also careful to maintain a high standard of coinage and low prices. According to the Tārikhb-i Kirmān, Sohar was still a shahr (a town), the shahr of 'Umān, a prosperous centre with a beautiful masjid (mosque), renowned for its bazaar, cosmopolitan society, business, and wealth ${ }^{17}$. Despite what some sources have to say, Sohar did not seem to have witnessed neither serious damages from the 1051 occupation nor any sharp break in its political and cultural role; conversely, it was largely to

16 Ibn al-Athīr, Al-kāmil...cit., vol. ix, pp. $387 f f$. See also V. Piacentini Fiorani, Beyond Ibn Hawqal's Bahr al-Fārs...cit., pp.117ff.

17 Vazīrī, Tārīkh-i Kirmān cit., vol. i, pp. 350-351; Muhammad ibn Ibrāhīm, Tārīkh-i Saljukiyān-i Kirmān cit., pp. $4 \mathrm{ff}$. 
benefit from the Seljuk military protection although, to the south along the coastal area, another centre of power began to rise and emerge: Qalhat, heralding the changing maritime orientation of $\mathrm{Oman}^{18}$. Once again, Mohammad ibn Ibrahim, the Tārīkh-i Kirmān, and Ibn al-Athir prove to be precise, objective, and reliable sources. Their information is well complemented with data from numismatics and archaeology ${ }^{19}$.

Malik Qavurd ibn Chaghri Beg the Seljuk had thus recomposed that 'triangle' already shaped by the Buyid political and military line: a territorial block encircling a vast liquid space at the core of the main mercantile international transactions, structured on a flexible administrative and institutional system based on the separation of the civil society (and its traditional forces) from the military, which allowed to the local social classes to stand up with their traditional roles and express their identity through local officials. This was the intrinsic feature of the Seljuk "art of government", a special balance of powers reinforced by the military shield of the Seljuk army, local autonomies and the moreorless benevolent governorship of local officials and Seljuk's family members. We are now confronted with a system that would be destined to survive Qavurd Khan and last for many centuries to come. Against this backdrop, the role of Oman began to rise, leaving its seal on the following centuries.

\subsection{Hormuz and its legacy}

The Kerman-Kij/Makran-Oman "allegiance" survived the disruption of the Turkish dominion and new foreign aspirations and attacks. The subtle network of matrimonial alliances and diplomatic under-

18 With regard to Qalat, excavations have been carried out since five years by a French team headed by Dr Axelle Rougeulle. The results so far achieved are overwhelming. They match the literary sources, and provide significant evidence of the role plaid by this centre, its rise, grandeur and decay.

19 See above and note (11). Extremely accurate are the studies by the late Nicholas Lowick, "Trade patterns on the Persian Gulf in the light of recent coin evidence”, in D. Kouymjian (ed.), Near Eastern Numismatics, Iconograpby, Epigraphy and History: Studies in Honour of George G. Miles, American University - Beirut 1974, pp. 319-333; Idem, "Further unpublished Islamic coins from the Persian Gulf", in Studia Iranica 11 (1982), pp. 247-261; Idem, "An Eleventh Century Coin Hoard from Ra's alKhaymah and the Question of Sohar's Decline", in Proceedings of the Seminar for Arabian Studies 16 (1986), pp. 89-100. 
standings kept firmly, and from the ashes of the Turkish empire a new order took shape and a new dominion imposed its maritime and mercantile laws and rules: the kingdom of Hormuz.

Heir of the Seljuk legacy, the ruler of Hormuz renewed and consolidated the pacts previously subscribed with the Omani ally. Around the second half of the $13^{\text {th }}$ Century, political contingencies and matrimonial alliances brought to the throne a remarkable personality, Mahmud Qalhati - of an Arab Omani origin, as his name points to: i.e. from Qalhat, that harbour-town between Sur and Muscat just mentioned above.

Alternating cunning and force, Mahmud Qalhati (12411277/1278) was the lucid interpreter of the new age. Well perceiving the new threats posed by the invasion of Turkish/Mongol peoples spilling down to the sea, lured by the wealth stocked along the caravan routes and in the same harbour town of Hormuz still on terrafirma, he reorganised the administrative and institutional structures of his dominion. Firstly, he continued to pay regular tributes to the powers on the Iranian continent, to guarantee access and safe passage of the caravans to and from the continental markets; then, he decided to shift the capital city from its ancient land location to an insular location on a small islet facing the present port of Bandar Abbas; at the same time, he set up a formidable defensive system by fortifying the core of the kingdom through the building - or refurbishing - of a double crown of fortifications on both the Iranian and Arab seaboards. After his death, the energetic rule of a Turkish slave regent for the infant prince, Baha al-Din Ayaz (1291-1311), further secured Hormuz and the allegiances with Kij and Oman, that had been the kernel of the whole maritime system. With Qalhati and Ayaz, the 'military' was no longer a foreign army but the expression of the very forces of the Gulf and its peoples, a solid combination of the land troops that Oman could put together with the fleets of the merchants that, when needed, became excellent warships. The system set up by the Seljuk sultans became a solid and well-structured reality. Matrimonial alliances reinforced understandings and further consolidated the cohesion between the three units of this territorial block. The civil society was expression of the very traditional force of the Gulf and its adjacent seas: a mobile, multi-confessional and pluralistic society, that collaborated and supported the centre, and provided the system with a bureaucratic written apparatus, a mercantile class, farmers and sailors, craftsmen: the economic and balancing factor of a 
worldwide maritime economic empire. The new city of Hormuz on the island of Jarun became the heart of one of the most fabulous maritime empires of its time (cartographic insert, Figs. 4-13).

Oman recomposed its traditional equilibriums. The unreliability of the treacherous Iranian aristocracy induced Salghur Shah ibn Turanshah II to drastically change the political ties. The embargo posed by this ruler at the end of the fifteenth century on all strategic raw materials in transit to Iranian harbours (such as peach, ropes, wood etc.) tilted seafaring and trade in favour of the Arabian seaboard and its towns.

At this very point, Oman became the pole of the whole Hormuzi structure - as Al-Salimi will soon enhance in his discourse: Qalhat would be appanage of the heir-Prince of Hormuz, Omani land-troops the nerve of the army, the merchants' fleets would become excellent warships when needed. The loyalty of the ra'ises of the fortresses of the seaboards and the hinterland would be the stern sentinels of this maritime and land system. The mercantile class with its agents and financial representatives was the network of all business revolving around the prince of $\mathrm{Hormuz}^{20}$.

At the start of the $16^{\text {th }}$ century, this well-structured system and the counsels of its astute vizier, Hajji 'Attar, allowed the young ruler of Hormuz, Sayf al-Din, to resist the arrival of the Portuguese fleet and its cannons. Loyalties and allegiances held on. After the death of Hajji'Attar in 1514, Sayf al-Din - trapped between the Portuguese fleet that had dismantled one by one its land fortresses and was now besieging the island, on the one hand, and the Safavid troops with their ferocious watchdogs, the Qizilbash, all along the Iranian seaboard, on the other, intrigued by an untrustworthy court, decided that the Portuguese were the minor threat and opened secret negotiations with them. The outcome was a Treaty of Friendship and Trade, officially signed in 1515. This allowed the system to reorganise its forces under

20 Archaeological evidence all along the Arabian, Iranian and Pakistani coastal regions, and in the hinterland, does confirm what contemporary literary sources have to say. New surveys and excavations give fresh telling data. In particular A. Rougeulle's excavations at Qalhat, D. Kennet's work at Rustaq, T. Power's in the Buraimi oasis, V. Piacentini and the late R. Besenval in Makran, some amongst many other renowned scholars. We are heartily grateful to the Sultanate of Oman and the Pakistani Federal and Provincial Authorities for allowing these researches, which are writing on the sand and on the rocks new astounding pages of history. 
the military shield of the Portuguese fleet and cannons, and some Portuguese garrisons on the Arabian seaboard. But the basic structures survived and the traditional forces of the Gulf revived. Hormuz and its allies were allowed to carry out their traffics along their traditional international maritime and land network, paying to the Captains of the Portuguese fortresses some special tributes; the Portuguese held the monopoly of spices and some other drugs. It seemed a convenient bargain and - de facto - did result in a positive affair. Hormuz would not be involved in the international competition that animated the Indian Ocean when new actors from Europe made their appearance and new economic forces entered the panorama.

Capitulation will take place only in the 1622, after a prolonged and debilitating siege by the joint forces of the East India Company and the Safavid emperors. Today, on this barren island, the desolated ruins of what had been once the magnificent core of Hormuz power, and common ditches are the sad testimony of the British fury and the ferocity of its Persian ally.

\section{CONCLUSiOnS}

And these are the events, how they evolved and developed, welldocumented and recorded by European archival sources and first-hand local contemporary literature and archaeological evidence.

Accordingly, it is possible to conclude that, for over three centuries, the mercantile town built on the island had been heart and mind of a new political-economic and cultural system and structure, already envisaged in the past and further developed during the previous centuries under the rule of other princes. After the $14^{\text {th }}$ Century, here, in the magnificent town built on this islet, merchants conveyed from all over the world to bargain, buy and sell precious goods in great request on Eastern and Western markets: silks and brocades, amber and incense, dyes, frankincense and precious/semi-precious stones, spices and perfumes, oyster-feathers and eggs and ivory from Africa, porcelains from China and south-east Asia, pearls - small and big of the rarest beauty - and slaves.

Yet, the heart could work and function only thanks to the firm support of the Omani partner in particular. By the end of the fifteenth century, the embargo of Iranian harbours proclaimed by Salghur Shah 
(1475-1505) proved to be energetic and efficient; it worked thanks to the collaboration of the coastal fortresses and their governors, and tilted the bulk of overseas mercantile traffic and business in favour of Oman. Sohar survived, but the once resplendent town is now depicted as a borough surrounded by few villages. Qalhat became the powerful Province of the Crown Prince of Hormuz, at the same time it was shelter when internal feuds and succession wars took place. Matrimonial links reinforced the traditional alliances with the tribes of the Omani interior. The ruler was a merchant himself, and his power was based on the mercantile, economic forces of the Gulf. But when enemies and opponents threatened the integrity of the kingdom, then the bulk of the army was now represented by the tribal troops of Oman. The ruler and his associated allies were aware of the new age opened by the arrival of the Portuguese; but this was not perceived as a direct threat, it was perceived and dealt with as a new age requiring a new calibration of tradition vis-à-vis a foreign modernity. The Safavid presence on the other side of the Gulf was conversely perceived as a menace, as a direct menace were perceived the arrogance of the new Turkish aristocracy and the ambiguity of the merchant families in Iran. When Shi'i Islam was proclaimed "state religion" of the new empire, then a cultural gap between the two boards was dug. But nothing was considered as irreversible. The Safavids were a "land" power and not sailors; Hormuz regularly paid the due tributes to the new Lords; however, those mercenary troops that were usually recruited from Lar and Jask were no longer considered as reliable. This urged the kingdom to reinforce the fortresses on both sides of the sea, as reinforced were the links with Omani tribal groups and farmers in the hinterland.

This was the legacy of the past, deeply rooted in the local costumes, firmly supported by a lively religious open-minded cultural approach. On the island of Jarun, at the shadow of the great Portuguese fortress, all foreigners were still welcomed without any discrimination and difference in terms of religion, race, language and colour...to the point that the kingdom - and Oman in particular - were commonly called as the Dār al-Amān, or the Land of Security, even in maps and charts of the Italian courts (Figs. 4-8, 12-13).

Multi-confessional and multi-ethnic, the kingdom of Hormuz will leave its imprint on the whole Gulf, but Oman, in particular, will inherit its culture and institutional system. Re-reading the main stages of the historic, political and socio-economic evolution of the Sultanate of 
Oman, it is well possible to assert that, today, neither the critical location of this country at the Gulf's entrance nor the numerous conflicts that are staining with blood the wider Middle-Eastern quadrant, have altered its cultural identity. Modernity and the progress of an unavoidable economic and social development have certainly opened up a new transitional phase, that H.M. Sultan Qaboos has faced and is facing through far-sighted, lucid plans and reforms, but also through balanced equilibriums between the various components of the Sultanate and its powerful tribes of the interior, on the one hand, and its neighbours and/or outlying countries on the other. All in all, Islam/Ibadism, tribalism, tradition, modernity have acquired a specific significance within the context of the rising importance of the Gulf region. In this same context and against the backdrop of the re-definition of the traditional international balances, Oman has followed a careful but coherent policy aimed at combining and consolidating shared and collective internal and international interests. Ibadism, the religious 'ideology' of the region since Early Islamic times, is playing a positive role, whose essential features today are moderation and perpetuation of an ancient liberal practise, whereas "religious pluralism" and "ethnic-cultural pluralism" represent the kernel of the Present and the premises of the Future. 

Intercultural relationships are well depicted in Western and Oriental cartography. Geographers and travellers minutely note the fabulous reality of the world revolving around Oman (XIII-XVII sec.).

(Figs. 4-13) 



\section{'Abd al-Razzāq of Samarqand describes in his historical account the Mirabilia of the City of Hormuz when he travelled there in the $1440 \mathrm{~s}$}

'Hormuz, which they also call Jarûn, is a port on the open sea which has no equal on the face of the earth...People of all religions, and even idolaters, meet in this city, and nobody permits any hostile gesture or injustice against them. And for this the city has been given the name of Dâr al-Amân (The A6ode of Security)'

Fig. 4. 

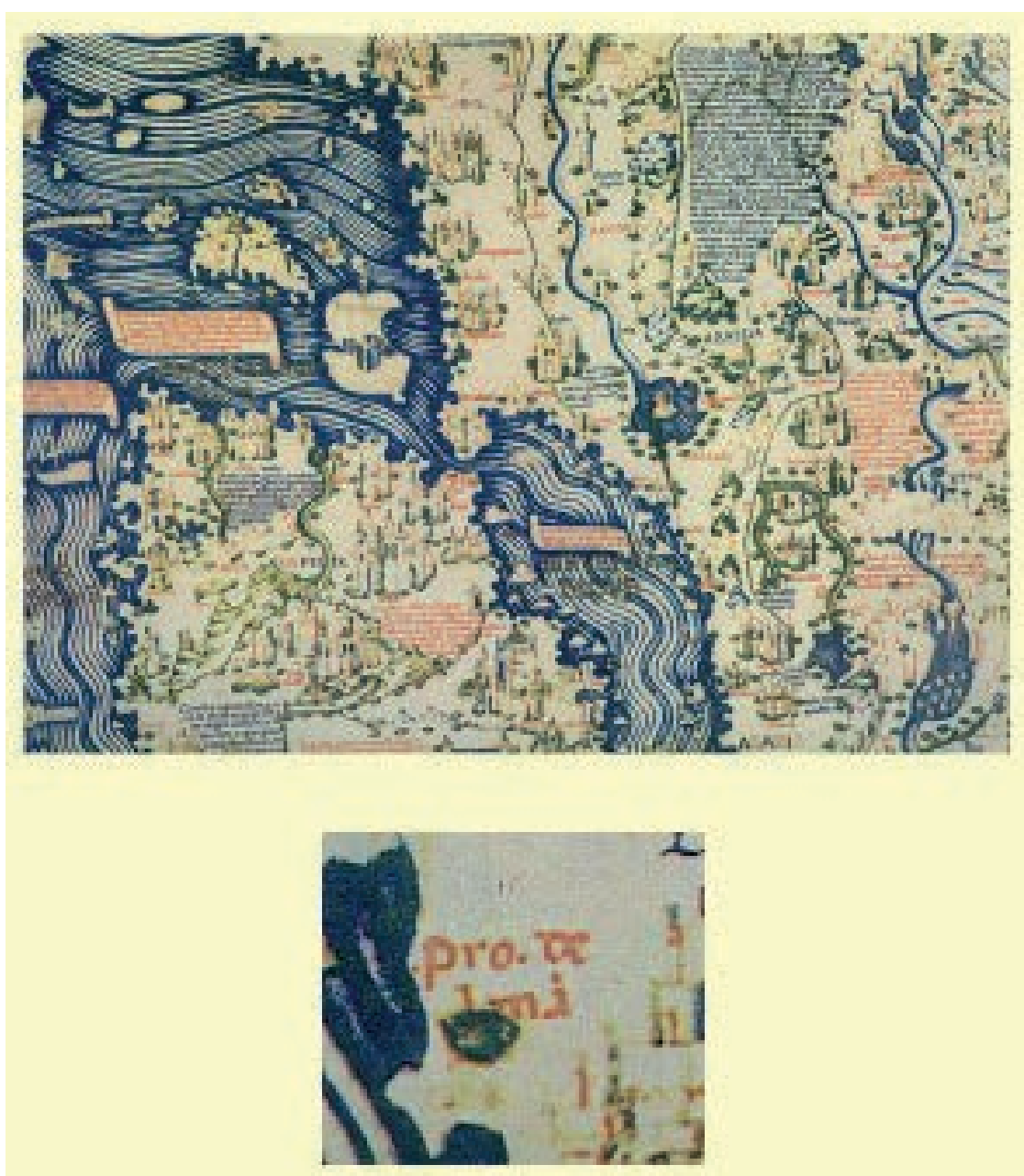

Fig. 5. Fra Mauro's Map, 1450, Provincia de Ima(n). 


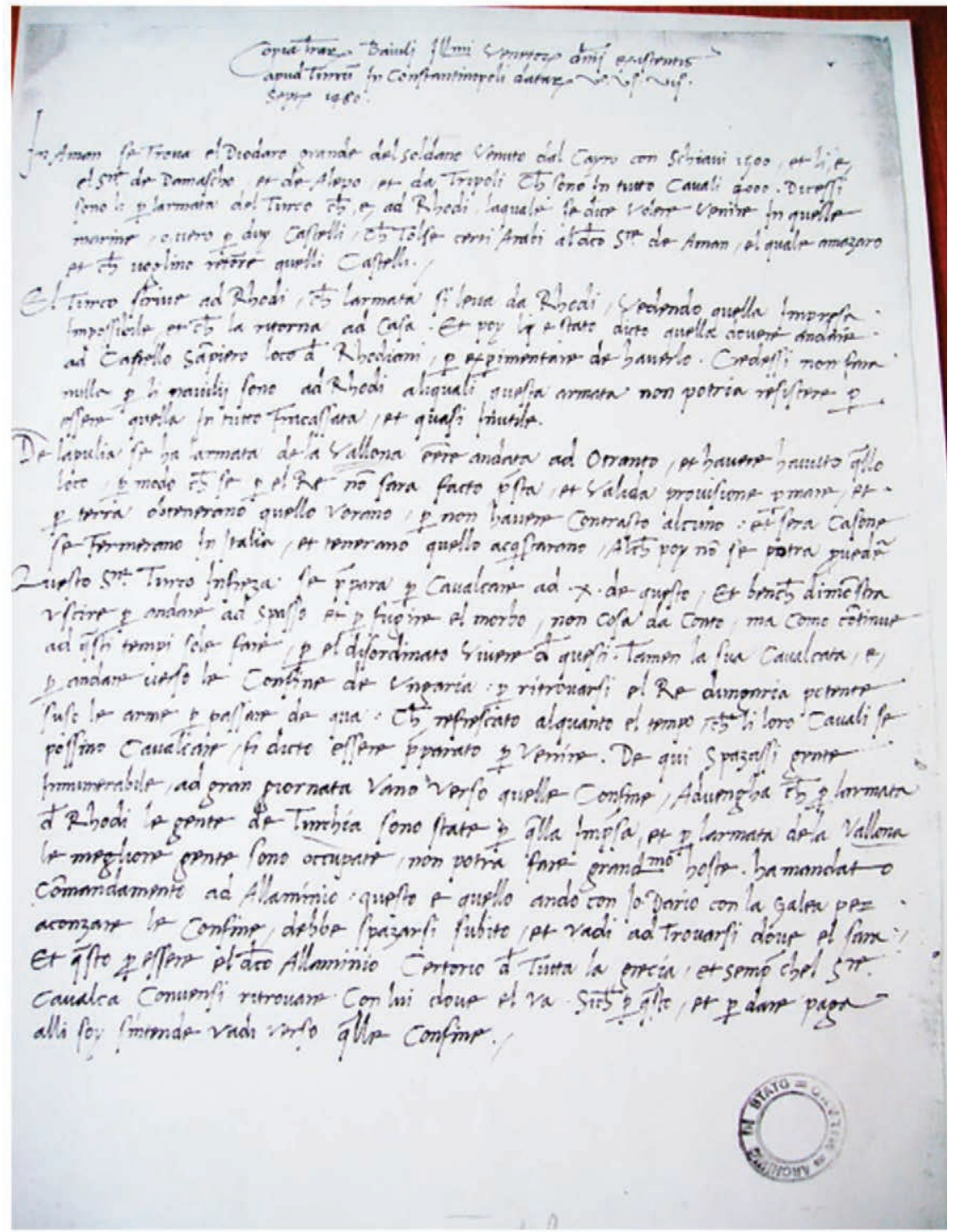

Fig. 6. Document mentioning "Aman", slaves and horses (1480). 


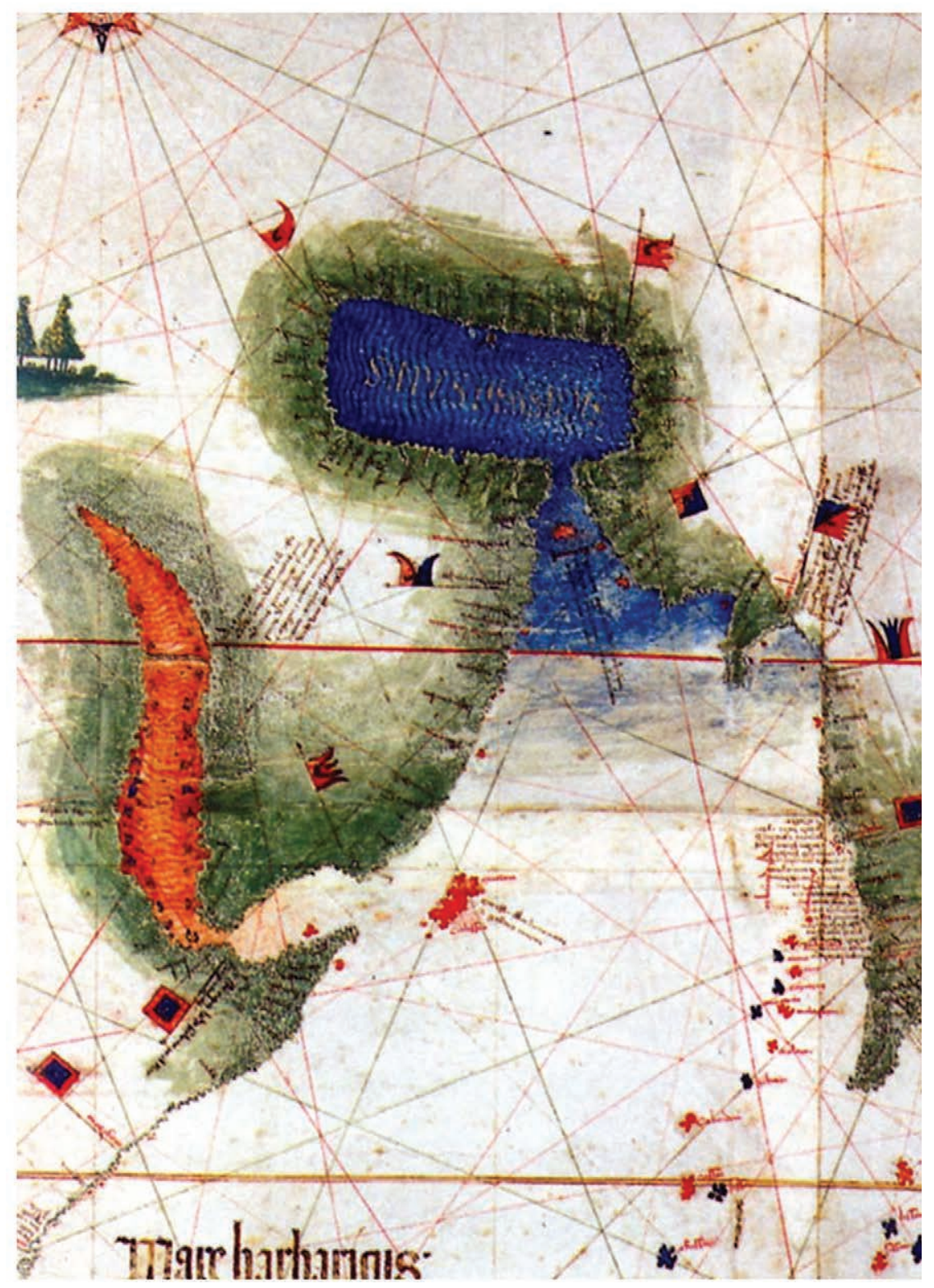

Fig. 7. Cantino, 1502, The Arabian Peninsula between the Gulf and the Red SeaModena Archive. 


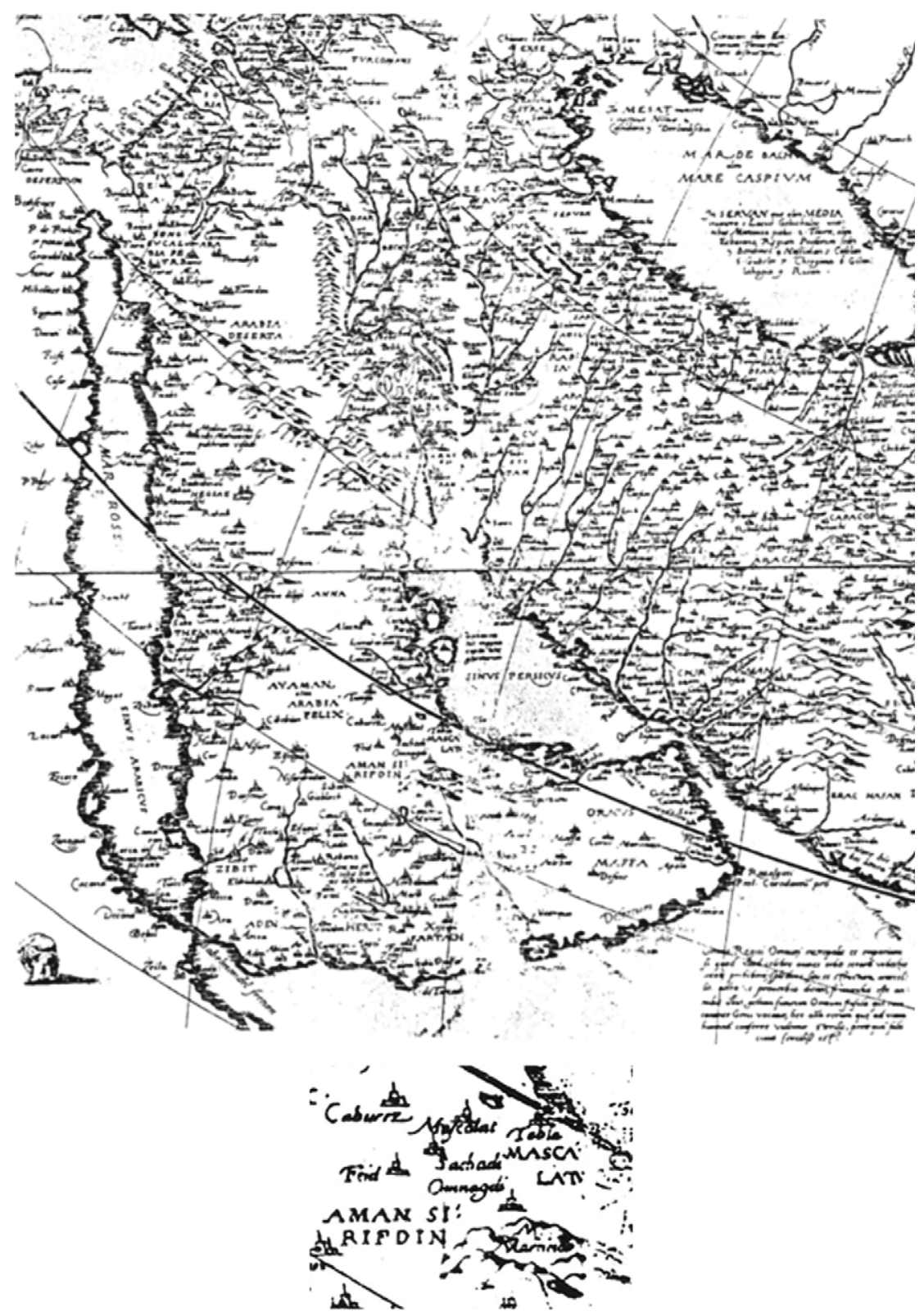

Fig. 8. "Aman" and "Mascalat" in the Italian Edition of Abramo Ortelius' Map of Asia. 


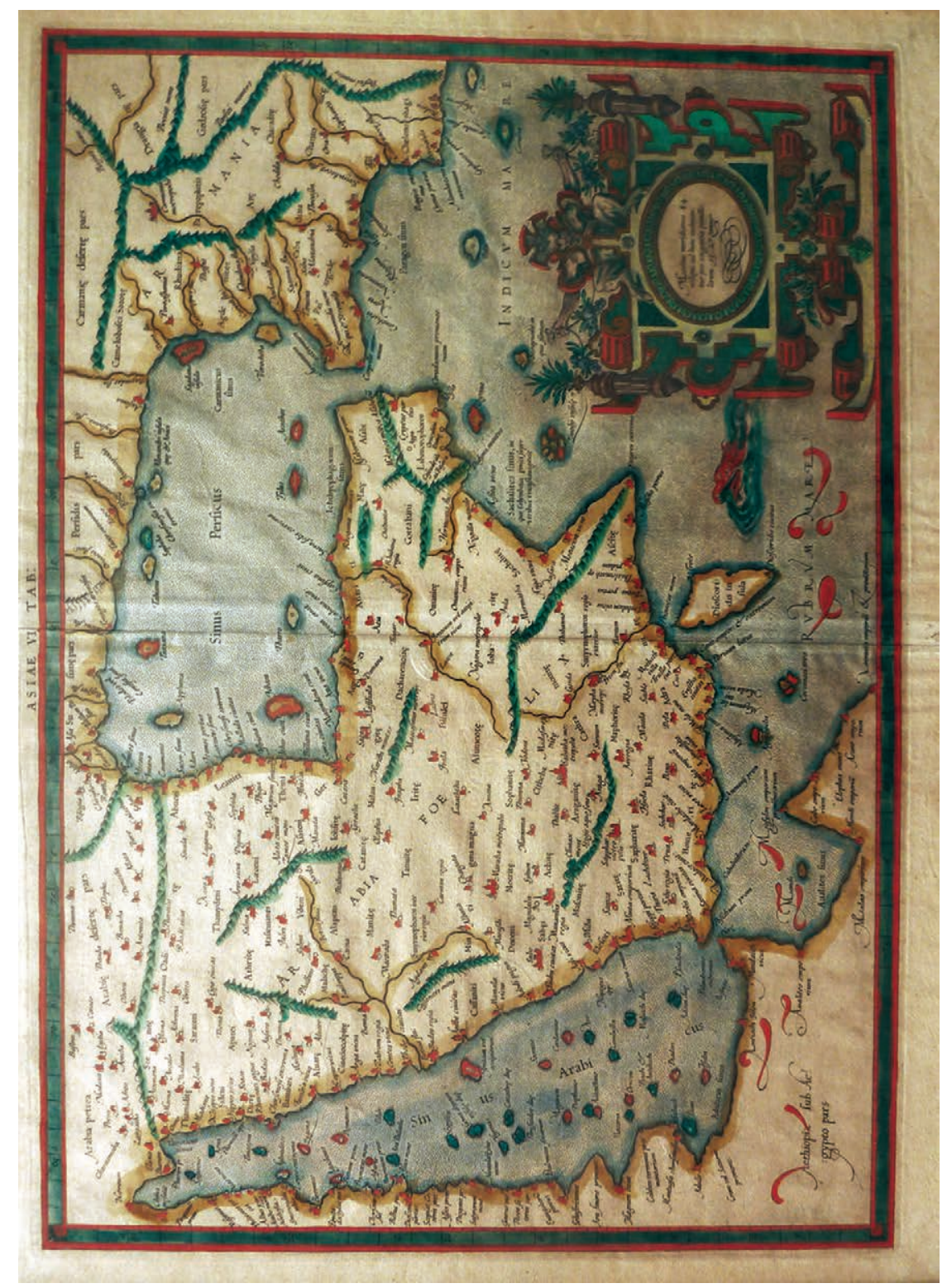

Fig. 9. Arabia Felix. Chart of the XVI C. 


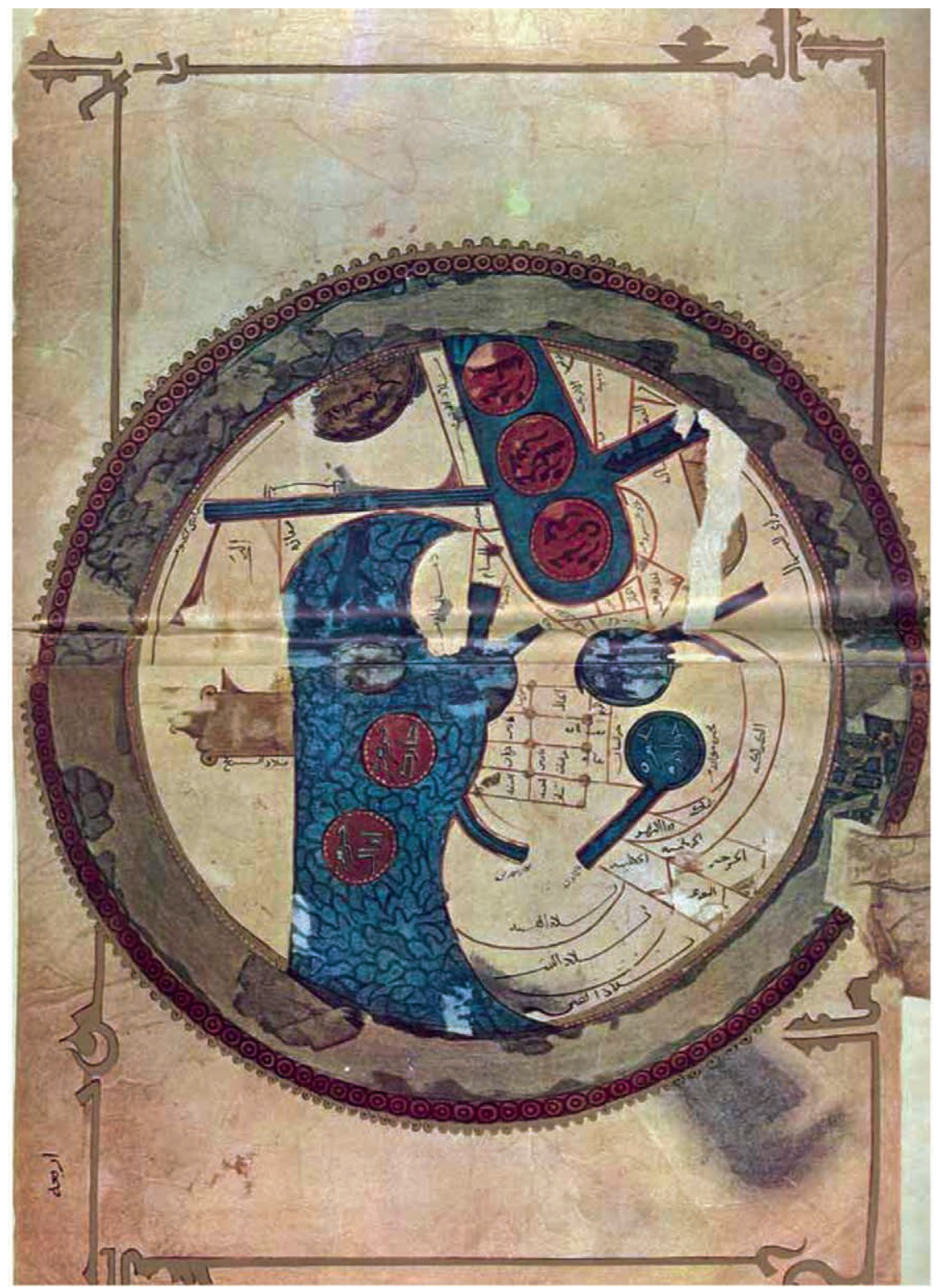

Fig. 10. Istākhrī, Kitāb al-masālik wa al-mamālik, written in the 340 AH / 950 CE circa. Manuscript dated 580 AH / 1193 CE. 


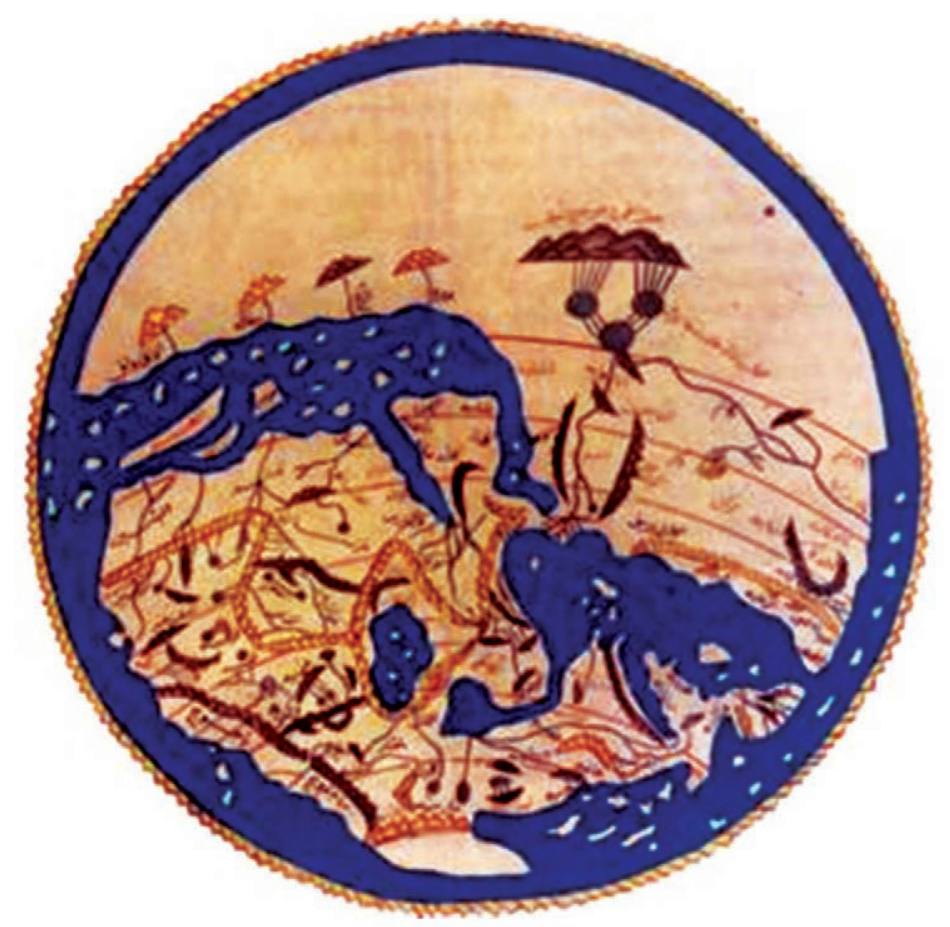

Fig. 11. Al-Idrīsī, Opus Geographicum: Map of the World. Idrisi's book was completed in 1154. 


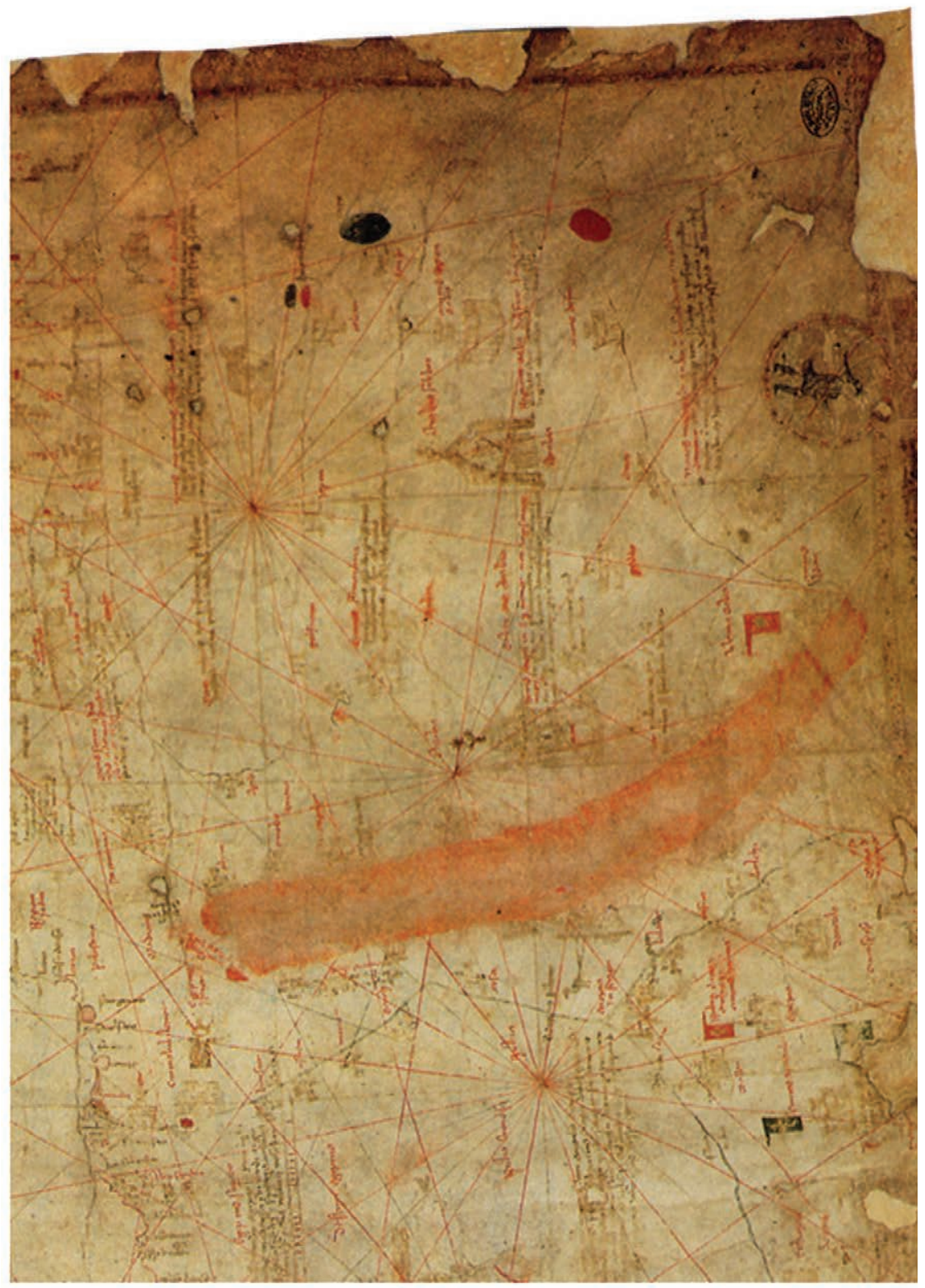

Fig. 12. Franciscus and Marcus Piciganus, 1367, the City of "Golfacam" [Khawr Fakkan]. 


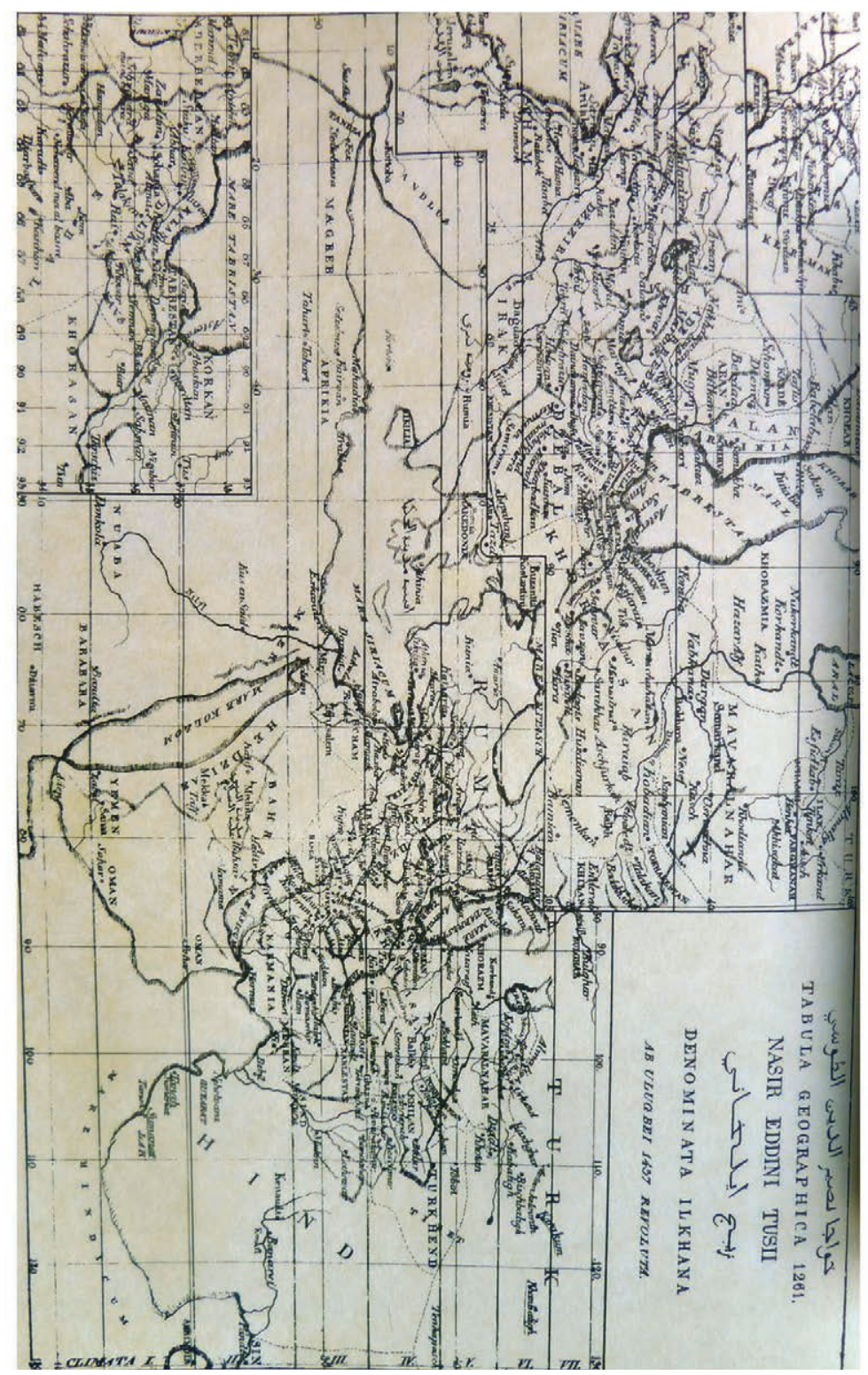

Fig. 13. Tabula Geographica Ilkhana, 1261 circa by Nāsir al - Dìn Tūsī, Al-Zij al-Ilkhānī, 1261, reconstruction by Joachim Lelewel, "Geography in the Middle Ages", Brussels, 1850, $\mathrm{Pl}$. XIX of the Atlas, who has currently udes the revision drawn by Ulugh Beg in $1471 \mathrm{c}$. 
Geographical and human environment

(Figs. 14-28) 


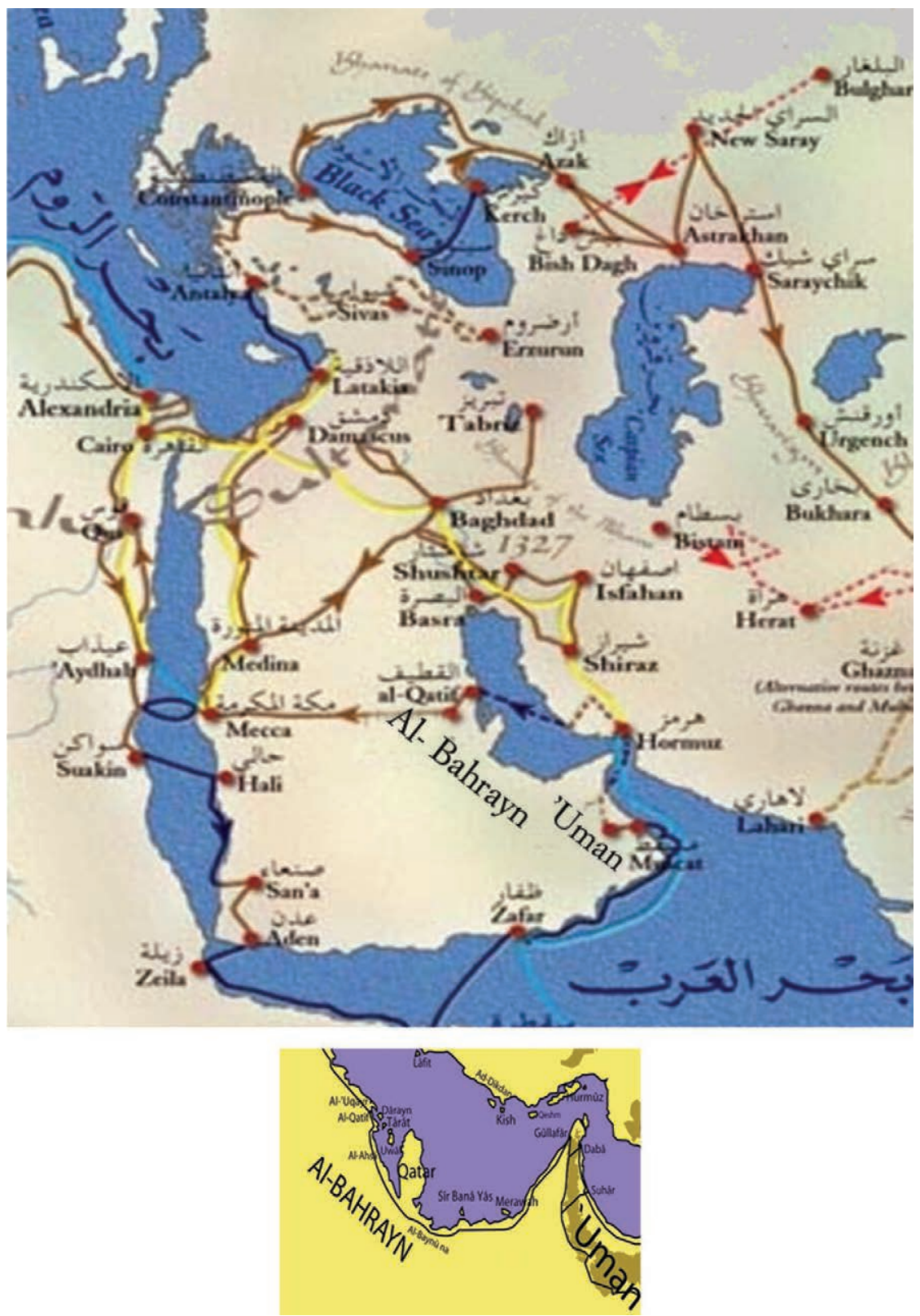

Fig. 14. Mercantile land routes XIII century CE. 


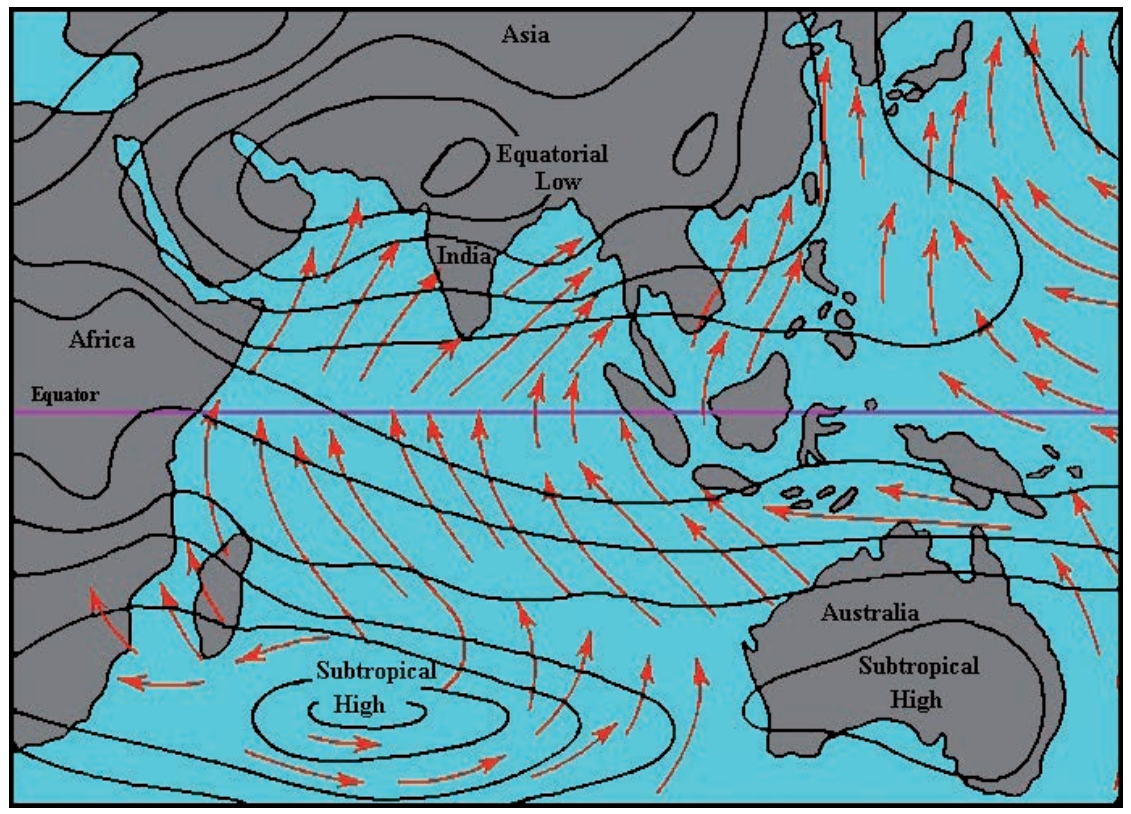

Fig. 15. Indian Ocean: maritime monsoon routes.

Figs. 16-18. Fortresses commanding the strategic passages to the deep hinterland.

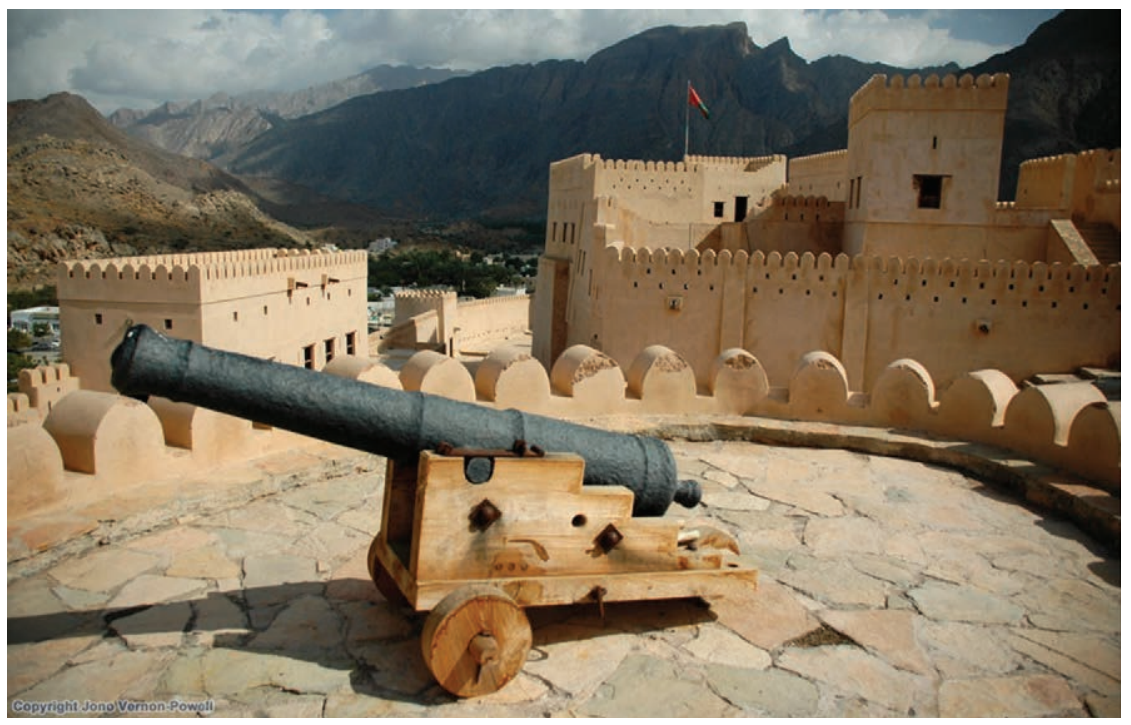

Fig. 16. 


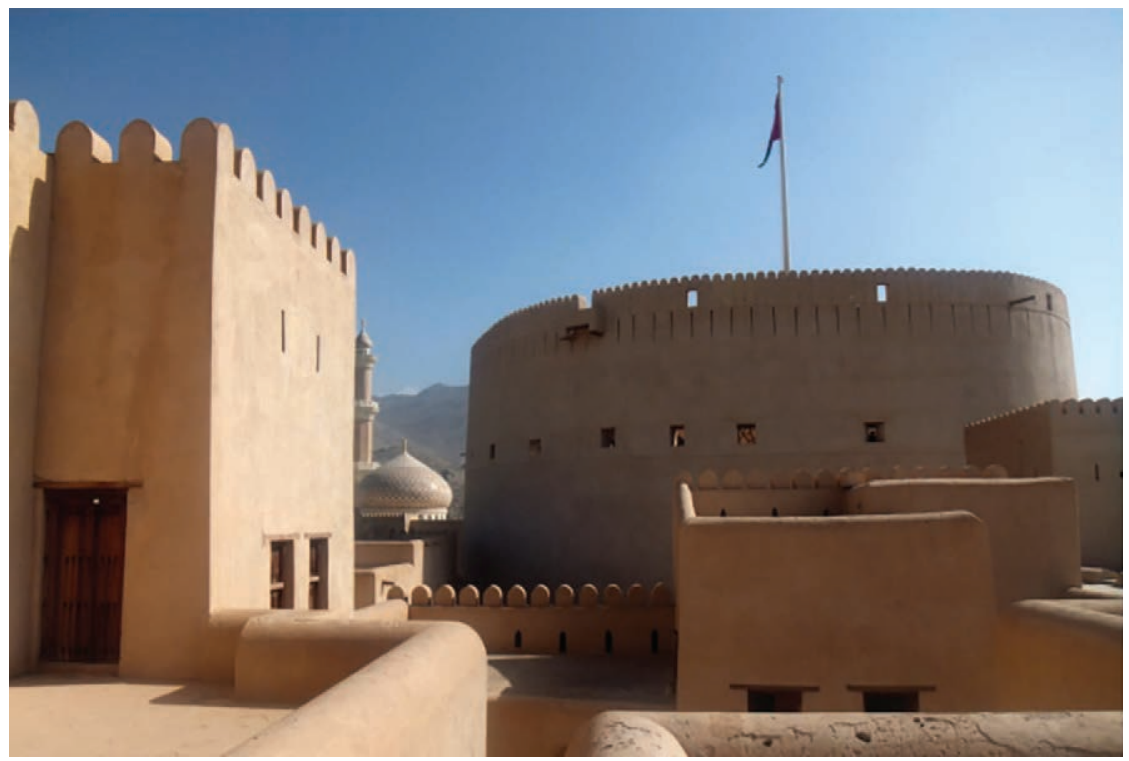

Fig. 17.

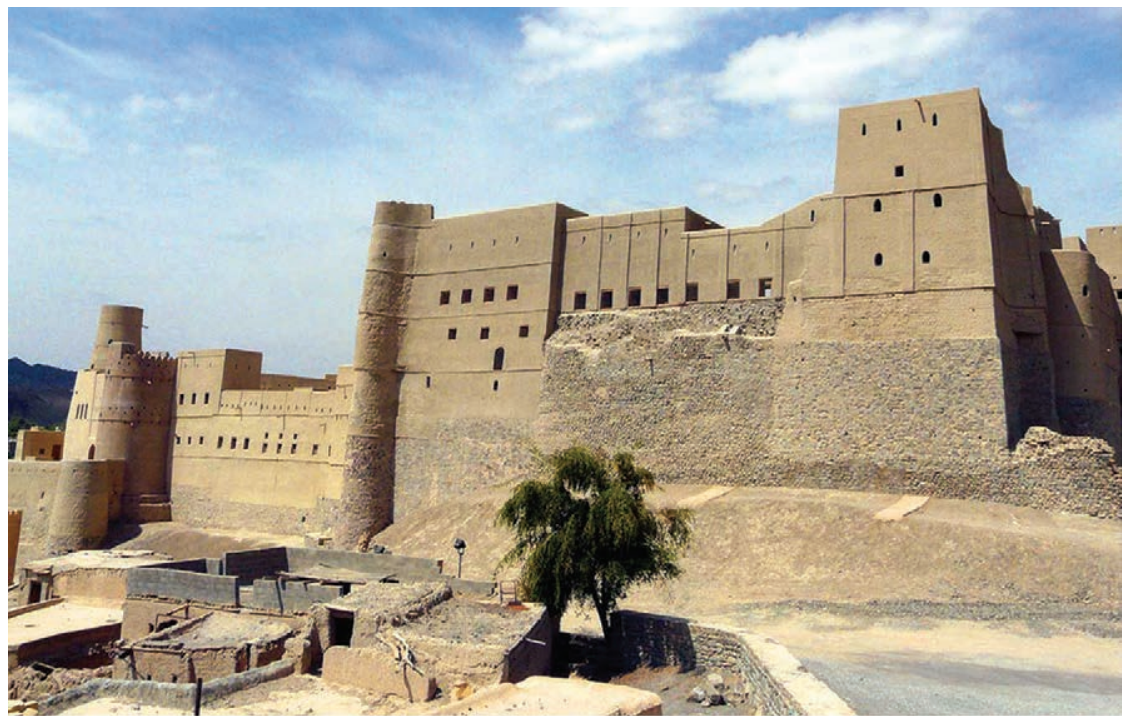

Fig. 18. 


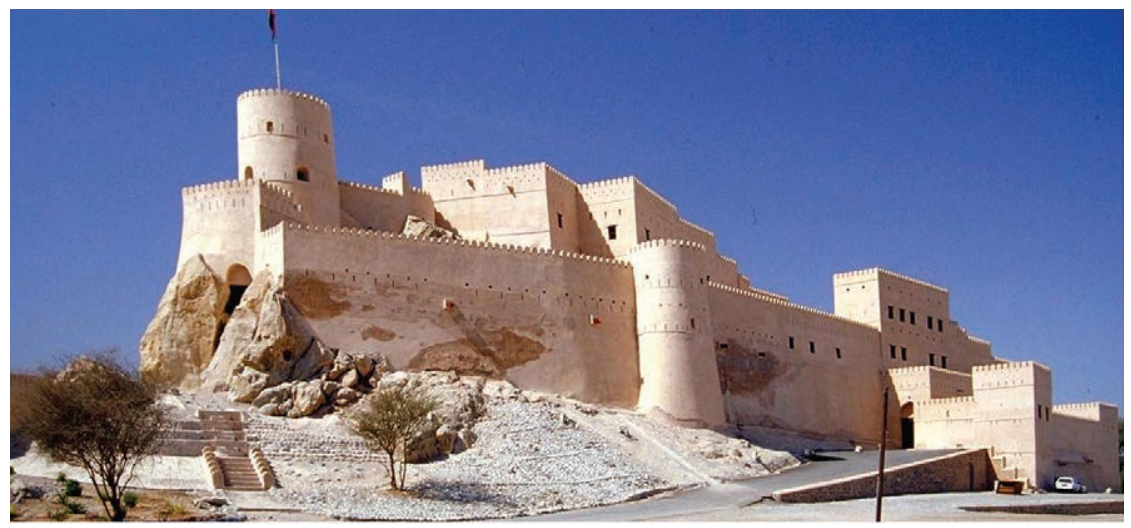

Fig. 19. Nakbal Fort.

Figs. 20-22. Irrigation chanals (aflāj).

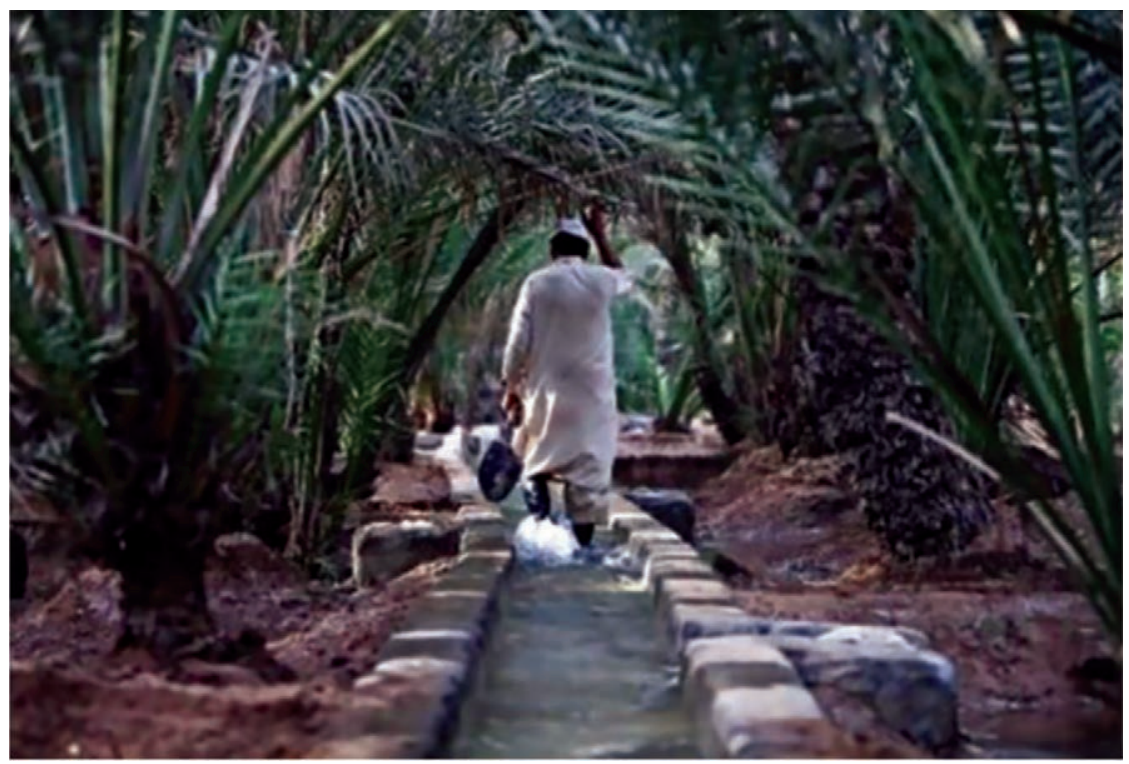

Fig. 20. 


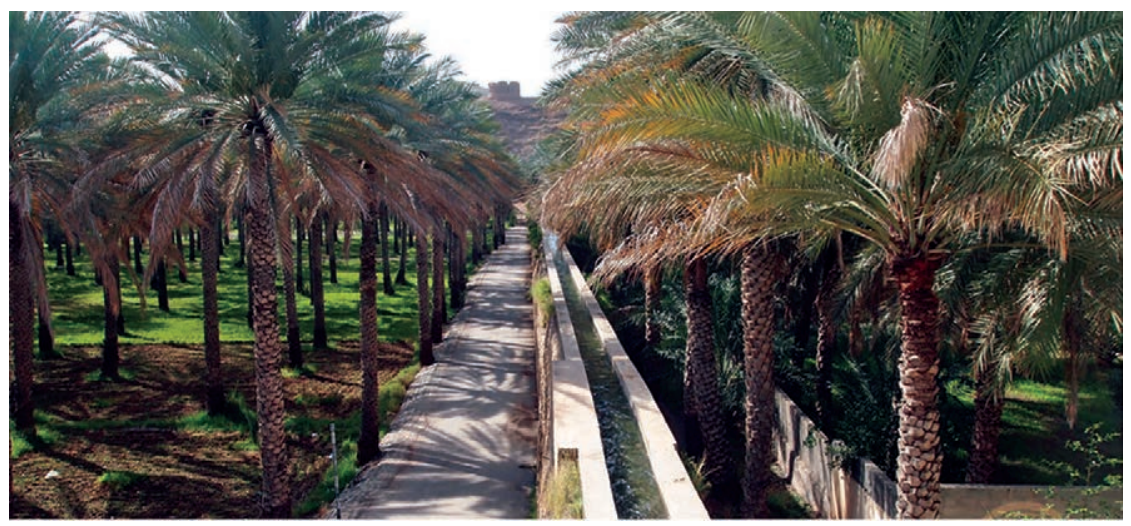

Fig. 21.

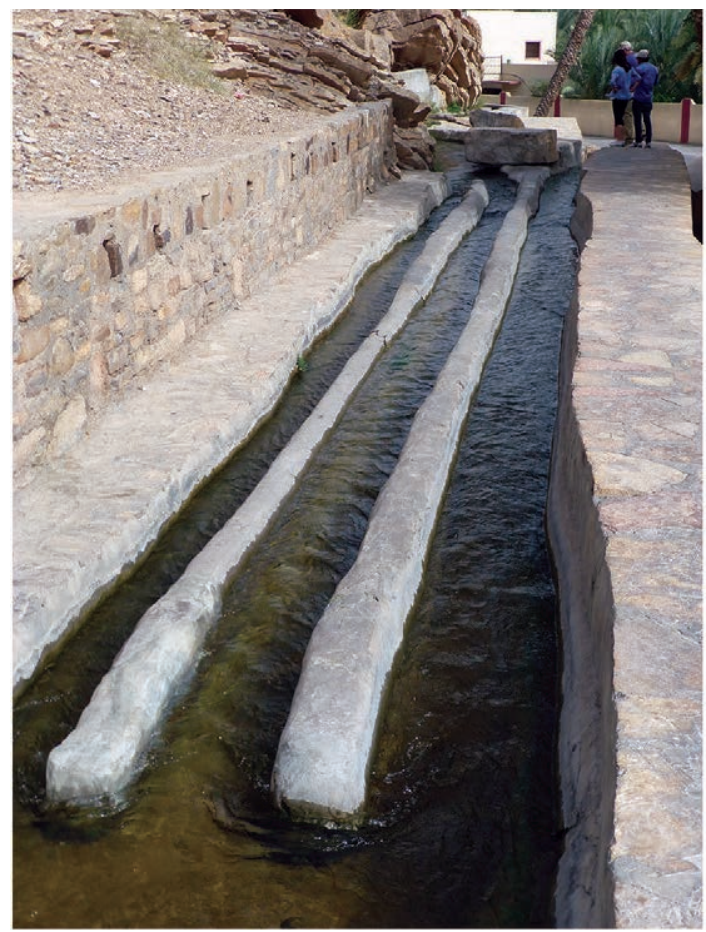

Fig. 22. 
Figs. 23-27. From Tradition to Modernity.

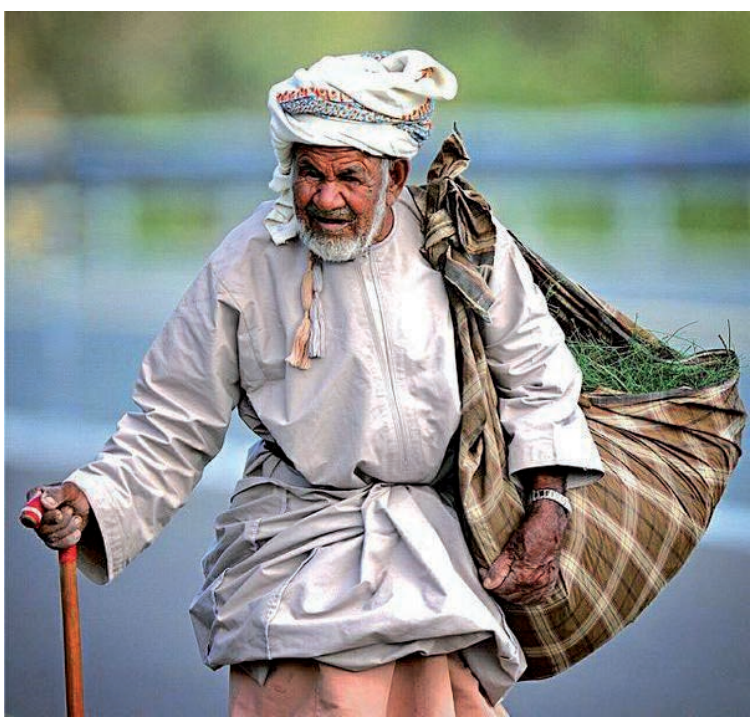

Fig. 23.

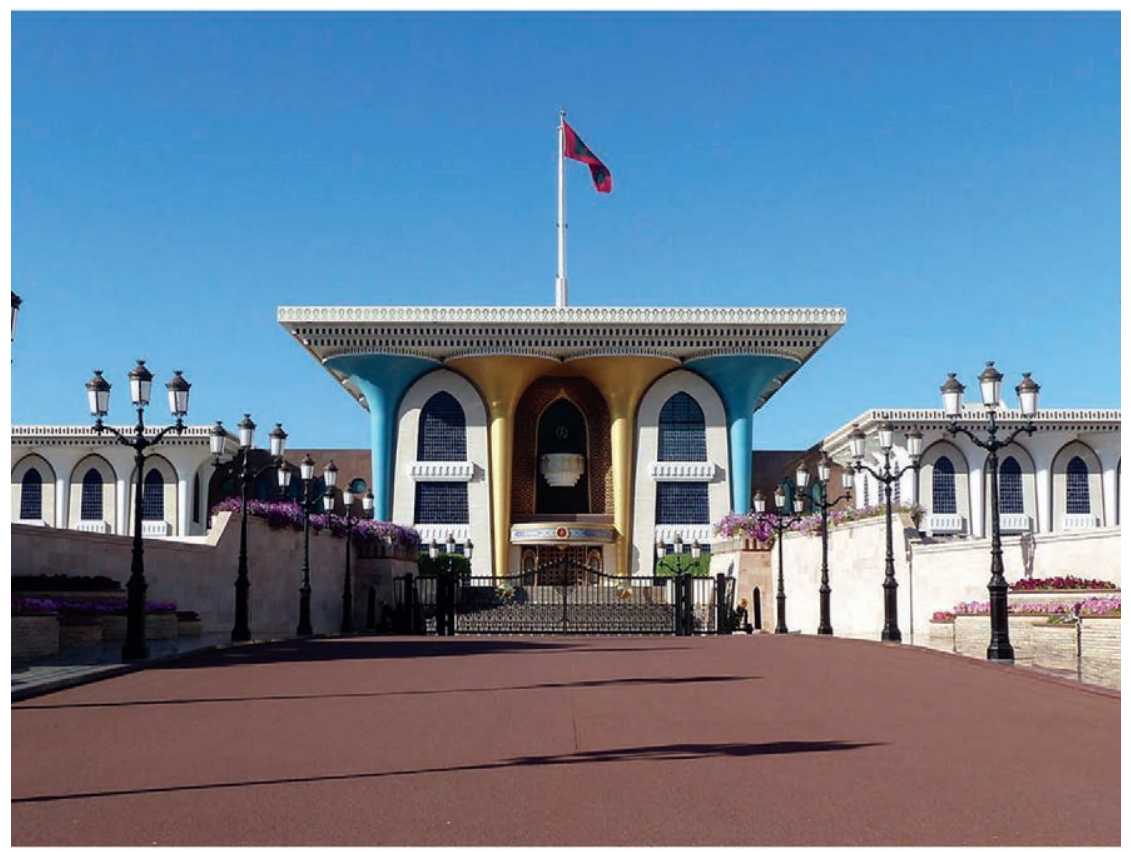

Fig. 24. 


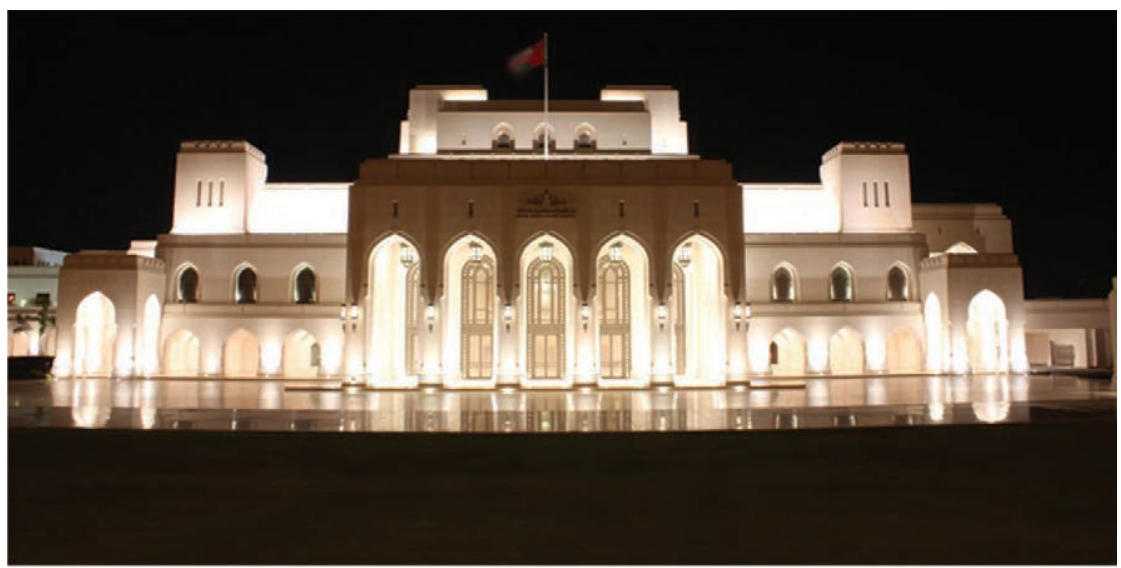

Fig. 25.

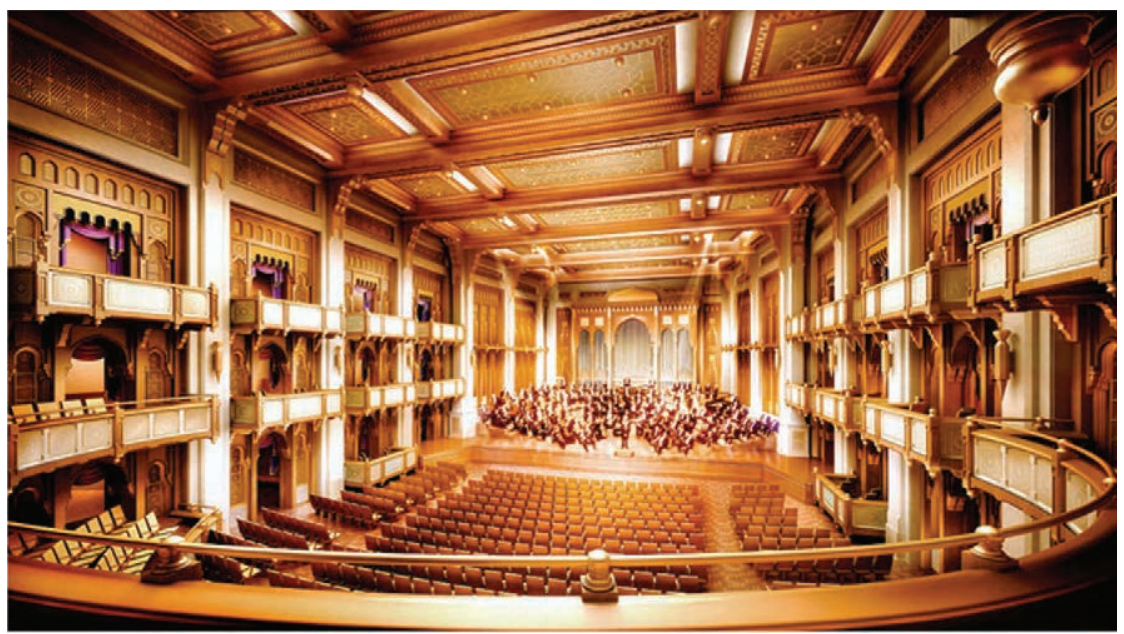

Fig. 26. 


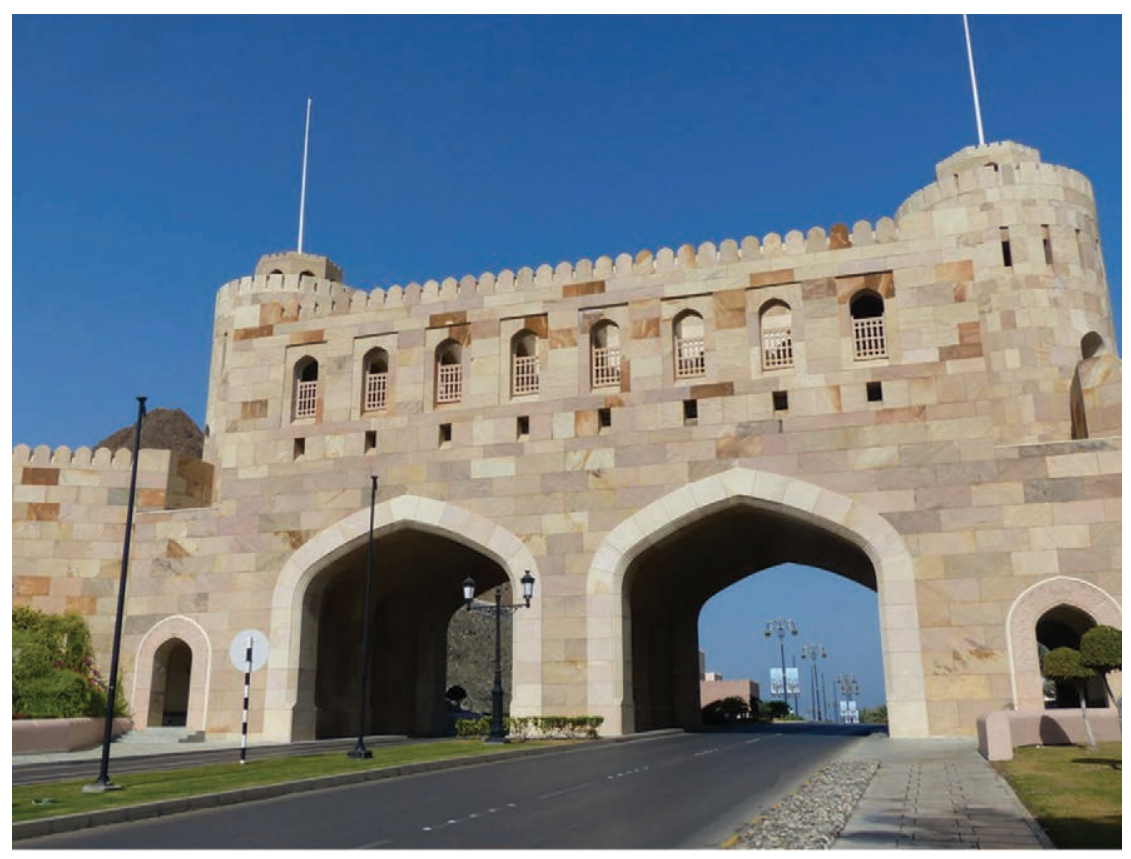

Fig. 27.

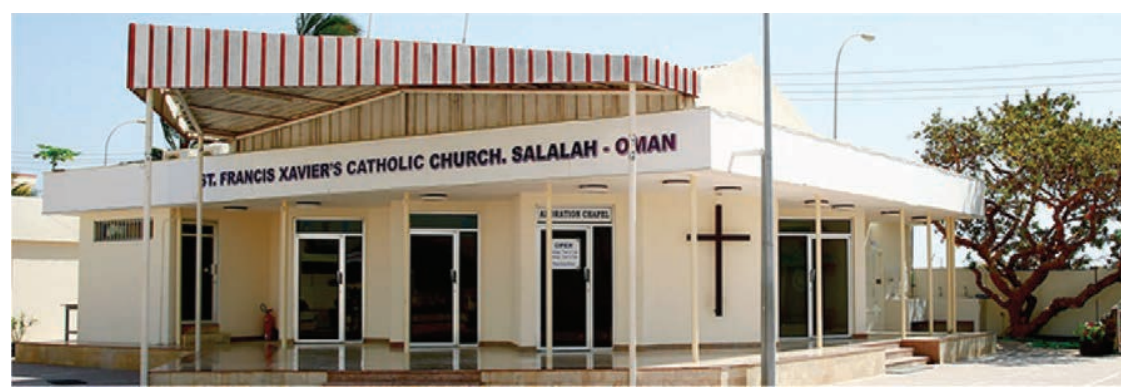

Fig. 28. Religious diversity within a multi-cultural framework. 